\title{
Cross-shelf phytoplankton pigment variability in the California Current
}

\author{
Andrew Thomas ${ }^{\mathrm{a}, *}$, P. Ted Strub ${ }^{\mathrm{b}}$ \\ ${ }^{a}$ School of Marine Sciences, University of Maine, Libby Hall 213, Orono, ME, USA \\ ${ }^{\mathrm{b}}$ College of Oceanic and Atmospheric Sciences, Oregon State University, Corvallis, OR, USA
}

Received 28 April 2000; accepted 20 November 2000

\begin{abstract}
Five years (1979-83) of satellite ocean color data from the coastal zone color scanner (CZCS) data are used to calculate cross-shelf transects of phytoplankton pigment concentrations in the California Current and quantify their seasonal and interannual variability. Alongshore means over six regions, Washingtonnorthern Oregon $\left(48.4-42.8^{\circ} \mathrm{N}\right)$, Cape Blanco to Cape Mendocino $\left(42.8-40.4^{\circ} \mathrm{N}\right)$, northern California $\left(40.4-37.8^{\circ} \mathrm{N}\right)$, central California $\left(37.8-34.5^{\circ} \mathrm{N}\right)$, northern Baja $\left(32.5-29.4^{\circ} \mathrm{N}\right)$ and southern Baja $(27.9-$ $22.9^{\circ} \mathrm{N}$ ) are used to contrast latitudinal differences. The general seasonal cycle shows minimum cross-shelf pigment extensions in March $\left(2.0 \mathrm{mg} \mathrm{m}^{-3}\right.$ isoline within $80 \mathrm{~km}$ of shore), expansion of pigment concentrations offshore in April and May often to the annual maximum $\left(2.0 \mathrm{mg} \mathrm{m}^{-3}\right.$ isoline up to $200 \mathrm{~km}$ offshore), a mid-summer (July-August) reduction in cross-shelf extension followed by a late summer (September) expansion and a fall collapse back towards the coast by late October. Amplitude of this seasonal pattern is minimum along the northern Baja coast and strongest off central California. Strong interannual variability is evident in both the timing and strength of these seasonal features. The most latitudinally consistent pattern of interannual variability is of negative anomalies and reduced concentrations during the 1983 El Nino. Time series of cross-shelf pigment distribution are compared quantitatively with concurrent alongshore wind stress and wind mixing $\left(U^{* 3}\right)$ from each region. Maximum correlations occur when pigment lags wind forcing by 1 or 2 ten-day periods. Strongest correlations are in the region from Cape Blanco to Cape Mendocino. Correlations are weaker both in the Pacific Northwest and off Baja. Correlations which excluded the anomalous conditions of 1983 are stronger in the three regions from Cape Blanco south to Point Conception suggesting that connections to wind forcing are stronger during non-El Nino years in these regions. Lastly, preliminary comparisons of the CZCS seasonal cycles are made to those evident in the first 19 months of SeaWiFS chlorophyll data which include the strong 1997-98 El Nino. (C) 2001 Elsevier Science Ltd. All rights reserved.
\end{abstract}

\footnotetext{
*Corresponding author.

E-mail address: thomas@maine.edu (A. Thomas).
} 


\section{Introduction}

Summer equatorward alongshore wind stress over the California Current induces an offshore Ekman transport, coastal upwelling of nutrient rich, colder, subsurface water and resultant increases in coastal primary productivity and phytoplankton concentrations. Earlier work has documented the latitudinally dependent seasonal variability of the alongshore wind stress (Bakun and Nelson, 1991; Strub et al., 1990). This forcing has weaker, but persistent mean monthly upwelling-favorable winds throughout the year at low latitudes (south of $\sim 30^{\circ} \mathrm{N}$ ), and a winter period of increasing intensity and temporal length of downwelling-favorable conditions (poleward alongshore wind stress) with increasing latitude. Summer upwelling-favorable wind stress reaches maximum strength off northern California (Bakun and Nelson, 1991). The transition between winter downwelling and summer upwelling is evident in both the wind record and coastal sea level (Huyer et al., 1979; Strub and James, 1988; Strub et al., 1987). This transition in alongshore wind stress, as well as seasonal changes in the strength of wind mixing (Thomas and Strub, 1989) and patterns of wind stress curl (Strub et al., 1990; Abbott and Barksdale, 1991) influence patterns of phytoplankton pigment distribution in the California Current and their seasonal and interannual variability. Results from the CTZ Experiment (Strub et al., 1991) suggest that the offshore boundary of the region of elevated pigment concentration appears to be constrained by the position of the main current jet and that wind forcing plays an important role in the temporal evolution of filaments of elevated pigment concentrations (Abbott and Barksdale, 1991).

Previous work using satellite data to examine variability in phytoplankton patterns has focussed either on relatively restricted time and/or space windows within the overall California Current (e.g. Abbott and Zion, 1985; Pelaez and McGowan, 1986; Smith et al., 1988; Michaelson et al., 1988; Thomas and Strub, 1990) or contrasts latitudinal and seasonal variability within specific regions over which differences between nearshore and offshore are evident but actual cross-shelf patterns of pigment concentration were averaged (Michaelson et al., 1988; Strub et al., 1990). A systematic analysis of temporal and latitudinal patterns of cross-shelf phytoplankton pigment distribution in the California Current has not been published. Such patterns, however, provide a biological estimate of the cross-shelf position of the main current jet and define the width of the biologically enriched California Current system, including the mean width of the productive region within which many commercially valuable species spawn, rear and/or migrate.

Satellite measurements provide time series of synoptic measurements of biological patterns over large spatial areas. NASA's coastal zone color scanner (CZCS) satellite mission imaged ocean color from late 1978 to mid-1986 (Evans and Gordon, 1994) allowing for an unprecedented temporal and spatial quantification of phytoplankton pigment concentrations. The California Current was one of the most frequently imaged regions of the global ocean and numerous studies have used the time series to examine aspects of the variability of pigment patterns (e.g. Fiedler, 1984; Smith et al., 1988; Strub et al., 1990; Thomas and Strub, 1989, 1990; Abbott and Barksdale, 1991). Individual images (e.g. Pelaez and McGowan, 1986; Simpson et al., 1986) illustrate the intense mesoscale dynamics associated pigment distribution.

Here we use the CZCS data set to calculate the seasonal and interannual variability of the crossshelf distributions of phytoplankton pigment concentrations in the California Current. Our goals 
are to quantify the large-scale mean seasonal variability in cross-shelf pigment distribution and its latitudinal variability, to identify interannual variability within this signal and to examine linkages between the pigment patterns and wind forcing. We approach these goals by contrasting latitudinal differences between six study regions (Fig. 1) from northern Washington $\left(48.4^{\circ} \mathrm{N}\right)$ to the southern tip of Baja $\left(22.9^{\circ} \mathrm{N}\right)$. Meridional averaging within the six regions reduces the influence of individual filaments, eddies and other mesoscale features to provide large-scale regional mean patterns. Lastly, we compare mean seasonal variability in the cross-shelf pigment distributions to cross-shelf chlorophyll profiles extracted from recently available SeaWiFS data. Our analysis documents the CZCS-measured pigment patterns from the 1979-83 period as a background against which future analyses of large-scale cross-shelf structure, using modern and temporally coincident satellite estimates of ocean color, temperature, wind and dynamic height, can be compared.

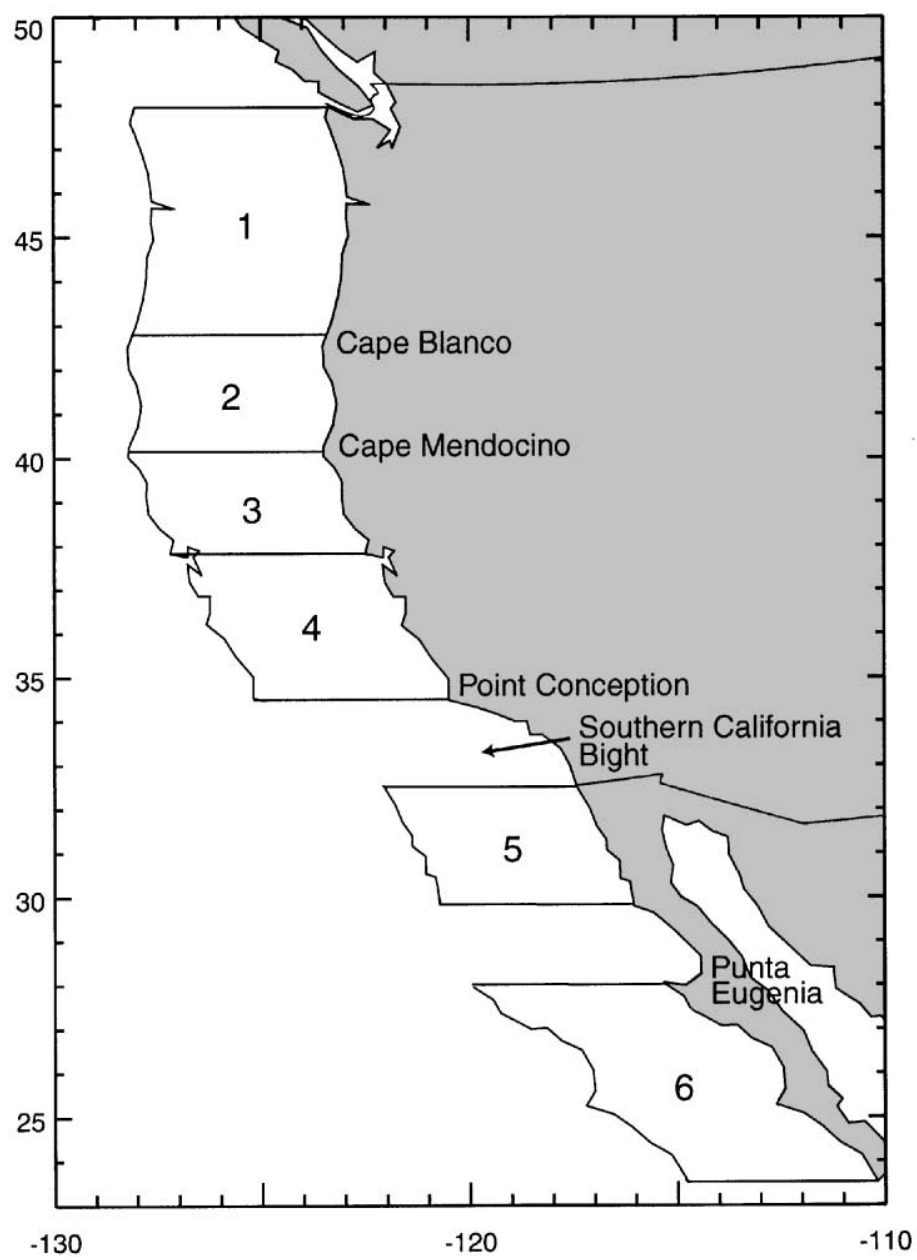

Fig. 1. The California Current study area, showing the six regions within which meridional averaging of pixels equidistant from the coast provides time series of cross-shelf satellite-measured phytoplankton pigment concentration. 


\section{Data and methods}

CZCS data from the study area are available from late 1978 to mid-1986. Previous work has shown that neither data coverage nor sensor stability was constant over this period (Evans and Gordon, 1994). Over the California Current, Thomas and Strub (1989, 1990) concluded that coverage from the years 1984 and 1985 was too sparse to form meaningful time series. Evans and Gordon (1994) show that data in the later years of the mission suffered most heavily from calibration degradation. For this study, we use data from the period 1979-83. All $4 \mathrm{~km}$ resolution Level 2 scenes from the study period over the California Current region were obtained from the NASA Goddard Space Flight Center archive. These were remapped to a standard projection covering the study area from $48.5^{\circ} \mathrm{N}$ to $22.5^{\circ} \mathrm{N}$ and offshore to $135^{\circ} \mathrm{W}$ (Fig. 1), retaining an approximately $4 \mathrm{~km}$ spatial resolution. Scenes from the same day were formed into a single image to produce a daily time series, which, due to clouds and missing data, contains many gaps in time and space.

Decorrelation time scales of SST and phytoplankton pigment in the California Current are approximately three days (Kelly, 1985; Denman and Abbott, 1988), with evidence that there are cross-shelf differences in both the actual time scales (2-4 days) and the linkage between phytoplankton and physical processes (Abbott and Letelier, 1998). Previous examination of the CZCS time series in eastern boundary current regions (Abbott and Zion, 1987) has shown that images are not randomly spaced in time, but are biased towards specific weather conditions. Clear images occur in groups separated by weather events (clouds). To average over individual events and over missing data periods, the daily images were formed into 10-day composites beginning January 1 in each year, providing 36 images in each of the study years. The 10-day period is a reasonable compromise between retaining sufficient temporal resolution to visualize seasonal patterns, filling missing data gaps and averaging over individual events.

Latitudinal differences in cross-shelf pigment distributions over the California Current were examined by dividing the study area into six regions. Latitudinal boundaries for these regions were subjectively chosen based on large-scale flow patterns, seasonality and hydrography (e.g. Lynn and Simpson, 1987; Hickey, 1998; Hill et al., 1998). These six regions (Fig. 1) were defined as (from north to south): Pacific Northwest $\left(48.4-42.8^{\circ} \mathrm{N}\right.$ ), Cape Blanco to Cape Mendocino $\left(42.8^{-}-40.4^{\circ} \mathrm{N}\right)$, Northern California $\left(40.4-37.8^{\circ} \mathrm{N}\right)$, Central California $\left(37.8-34.5^{\circ} \mathrm{N}\right)$, Northern Baja $\left(32.5-29.4^{\circ} \mathrm{N}\right)$ and Southern Baja $\left(27.9-22.9^{\circ} \mathrm{N}\right)$. These latitudinal ranges indicate two gaps which were purposefully left in the coverage. The Southern California Bight region was excluded from the analysis for a number of reasons. Strongly varying coastal orientation in this region prevents assignment of a unique direction which would capture crossshelf pigment structure in a manner comparable to the other regions. Cross-shelf pigment patterns in this area are also complicated by two factors which have no analogs in the other study regions: the Channel Islands with any elevated pigments in their vicinity, and the presence of elevated offshore pigment concentrations dissociated from the coast and not a result of local coastal upwelling, which come from advection south from Point Conception into the offshore and zonally oriented Ensenada frontal region (Pelaez and McGowan, 1986; Thomas and Strub, 1990). Crossshelf pigment patterns are also complicated by the coastal orientation and offshore islands immediately north of Punta Eugenia $\left(28^{\circ} \mathrm{N}\right)$ in the center of the Baja peninsula. This region was also excluded. 
Cross-shelf profiles of phytoplankton pigment concentration in each of the six regions were constructed by subsampling the 10-day composite scenes. A single mean cross-shelf profile was calculated within each of the six regions by latitudinally averaging pixels equidistant from shore, beginning at the pixel closest to the coast and progressing west. This provides cross-shelf profiles representative of mean conditions over relatively large sections of the coast, reduces (but does not eliminate) gaps in the time series due to missing data and smooths extreme values. Missing data in the time series of cross-shelf transects were filled by two steps of linear interpolation. First, spatial interpolation over cross-shelf distances of $20 \mathrm{~km}$ ( 5 pixels) within each time period was carried out. Gaps still present after this spatial interpolation were then filled by temporal interpolation between adjacent 10-day periods. Any remaining gaps were left unfilled.

As with all measurements, the CZCS estimates of pigment concentration contain errors and biases which are discussed by Strub et al. (1990), Abbott and Barksdale (1991) and Evans and Gordon (1994) and are not repeated here. Chavez (1995) shows that climatological mean CZCS pigment concentrations (1978-86) along a $250 \mathrm{~km}$ cross-shelf transect in the Monterey Bay region $\left(37^{\circ} \mathrm{N}\right)$ closely approximate a ship-measured surface chlorophyll climatology. The majority of previously published analyses of CZCS data over the California Current (see McClain, 1993) used data from the first processing of pigment concentrations which used a single scattering algorithm for atmospheric correction. Artificially high pigment returns at large solar zenith angles in these data (Gordon et al., 1988; Strub et al., 1990) prevent accurate interpretation of winter data at latitudes greater than approximately $40^{\circ} \mathrm{N}$. Preliminary results from reprocessed CZCS data set which use a multiple Rayleigh scattering algorithm suggested that the improved atmospheric correction reduced, but did not eliminate, this problem (Strub et al., 1990). Tests (not presented) with the multiple scattering corrected data which we use here indicated CZCS pigment concentrations greater than $3.0 \mathrm{mg} \mathrm{m}^{-3}$ between the coast and extending up to $400 \mathrm{~km}$ offshore north of $40^{\circ} \mathrm{N}$ in winter (November-February) in at least two of the five years, which does not seem realistic when compared to in situ data (Landry et al., 1989). Chavez (1995) shows that an offshore winter maximum is present in both in situ and CZCS data at $37^{\circ} \mathrm{N}$, but that at this latitude, climatological winter satellite returns overestimated pigment concentrations. These results suggest that while a general offshore expansion of California Current characteristics, including elevated pigments, occurs during winter at higher latitudes (Thomas et al., 1994; Strub and James, 2000), the absolute concentrations in the CZCS data are strongly suspect. Due to this continued uncertainty about winter pigment concentrations in the CZCS data set, we do not present pigment concentrations for November-February over the four northern study regions (north of $34.5^{\circ} \mathrm{N}$ ).

Wind data are the twice daily $2.5^{\circ}$ resolution surface vector products from NCEP, temporally subset to our CZCS study period (1979-83). These data were then spatially subset to the study area and the wind stress at each grid point was calculated. These vectors were interpolated to locations $50 \mathrm{~km}$ offshore at the latitudinal center of each of the six study regions. The alongshore component of wind stress and the non-directional strength of wind mixing on the ocean surface (parameterized as $U^{* 3}$ ) were then calculated using standard formulas with a constant drag coefficient of $C_{D}=1.3 \times 10^{-3}$ and a constant air density of $1.3 \mathrm{~kg} \mathrm{~m}^{-3}$. These twice daily values were then formed into 10-day temporal means within each year to match those of the CZCS data. 


\section{Results and discussion}

\subsection{Cross-shelf phytoplankton pigment patterns}

Phytoplankton pigment distributions from each of the five years of the CZCS mission are shown in Fig. 2, plotted as a function of time and cross-shelf distance in each of the six latitudinal regions of the California Current. Temporal and spatial (latitudinal) averaging within each region smooths individual mesoscale features such as filaments and eddy structures, providing a largescale overview of the seasonal and interannual variability of cross-shelf pigment structure. Anomalies shown in each figure, calculated as the deviation from the five-year mean at each timespace location, highlight interannual differences. This five-year mean is presented in Fig. 3.

In the Pacific Northwest region $\left(42.8-48.4^{\circ} \mathrm{N}\right.$, Fig. $2 \mathrm{a}$ ) concentrations greater than $3.0 \mathrm{mg} \mathrm{m}^{-3}$ are present throughout the spring-summer-fall within $40 \mathrm{~km}$ of shore, rarely expanding offshore as far as $100 \mathrm{~km}$. Lowest concentrations $\left(<0.25 \mathrm{mg} \mathrm{m}^{-3}\right)$ are usually over $200 \mathrm{~km}$ offshore, intruding towards the coast most closely in mid-summer (June-July). In each year, two episodes of seasonal offshore expansion of elevated pigments occur, one in spring and another in summer. The timing of the first of these episodes varies, occurring in early April in 1980, but not until late May in 1983. The second offshore expansion occurs in August. Patterns in 1979 and 1981 also indicate that offshore increases in concentration early in the season (March-April) can be temporally dissociated from increases nearshore (June). In 1981-83, elevated concentrations offshore at the beginning and end of the time series presented are difficult to distinguish from an overall winter increase (not shown, see Section 2) possibly due, at least in part, to insufficient atmospheric correction. Two episodes of increased concentration and offshore expansion are still evident, however, in patterns within $150 \mathrm{~km}$ of shore. This temporal pattern is consistent with climatologies of in situ data off Washington shown by Landry et al. (1989). These authors show a single early summer (May-June) peak in vertically integrated chlorophyll within $50 \mathrm{~km}$ of shore, but two episodes (February-April and October) of increased concentration between 50 and $90 \mathrm{~km}$ offshore separated by mid-summer lower concentrations. This pattern, however, was not present off Oregon. The anomalies in Fig. 2 document the spatial and temporal extent of interannual variability. Maximum positive anomalies in the CZCS data occur in 1981 in the latter half of the seasonal cycle in the $100 \mathrm{~km}$ closest to shore, extending out to $350 \mathrm{~km}$ offshore in August. In 1982, positive anomalies occur in the beginning of the seasonal cycle within approximately $150 \mathrm{~km}$ of shore, lasting until mid-June. Maximum negative anomalies occur in 1979 when concentrations within $100 \mathrm{~km}$ of shore are low early (March-April) and late (August-October) in the seasonal cycle. Large negative anomalies are evident again in 1980, when mid-summer (centered in June) concentrations are low within $100 \mathrm{~km}$ of shore.

In the region from Cape Blanco to Cape Mendocino (40.4-42. ${ }^{\circ} \mathrm{N}$, Fig. $2 \mathrm{~b}$ ) the seasonal cycle shows stronger interannual variability than that further north. The bimodal increase in concentrations and offshore extension each year within $100 \mathrm{~km}$ of the coast is less evident than that further north, primarily due to the reduced amplitude of the early season increase. Further offshore $(>100 \mathrm{~km})$, however, two seasonal increases are evident in all years, albeit at lower concentrations $\left(1.0-2.0 \mathrm{mg} \mathrm{m}^{-3}\right)$ than those in the Pacific Northwest. There is considerable interannual variability in the timing and offshore extent of the major seasonal pigment increase over the five years of data. Using the offshore position of the $2.0 \mathrm{mg} \mathrm{m}^{-3}$ isoline as a metric of 

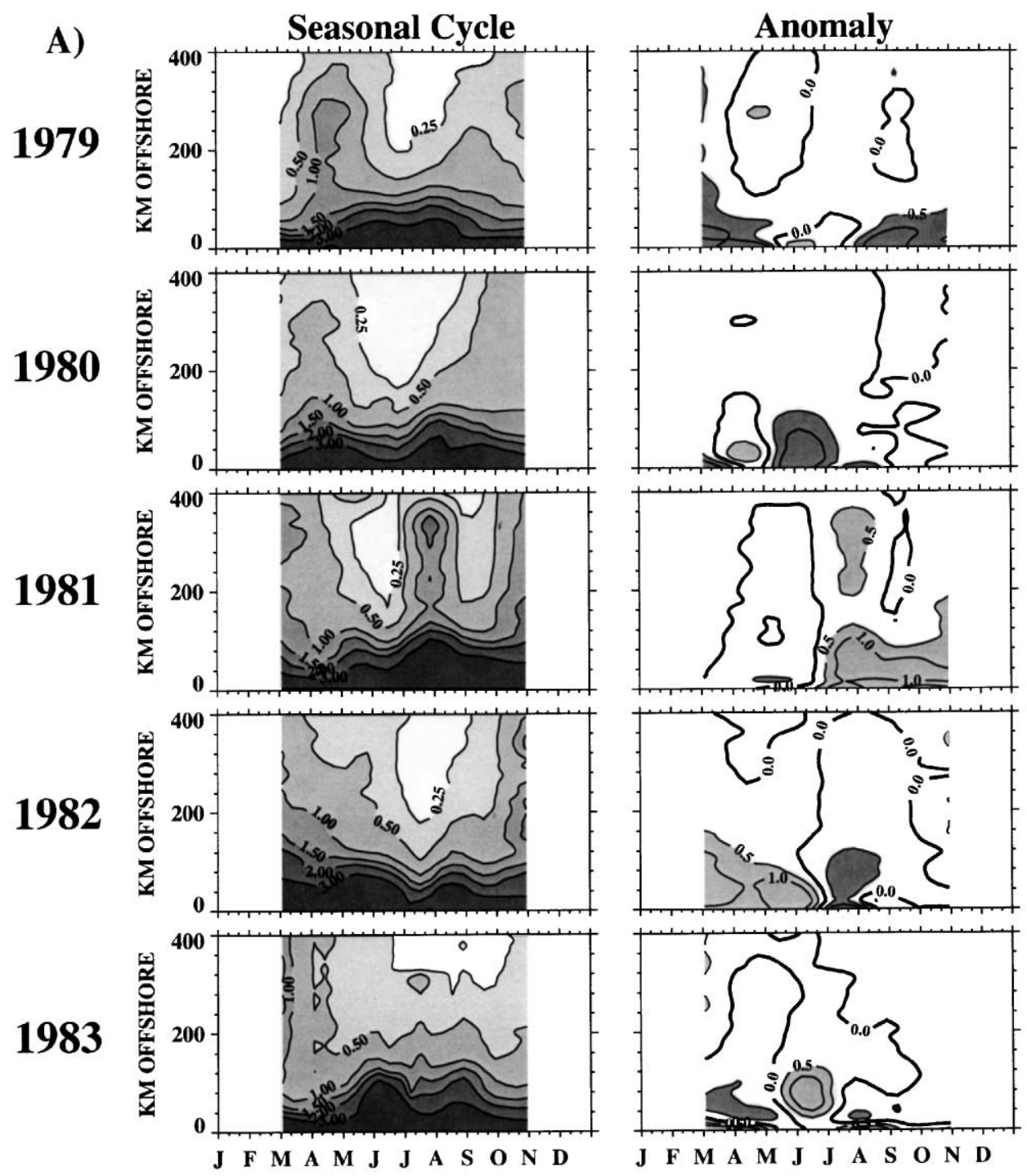

Fig. 2. CZCS phytoplankton pigment concentrations $\left(\mathrm{mg} \mathrm{m}^{-3}\right)$ in each study year, contoured as a function of crossshelf distance and time for (a) Region 1, the Pacific Northwest, (b) Region 2, Cape Blanco to Cape Mendocino, (c) Region 3, Northern California, (d) Region 4, Central California, (e) Region 5, Northern Baja and (f) Region 6, Southern Baja. Also shown for each region and year are contours of the pigment concentration anomalies, formed as the difference between individual years and the five-year mean (see Fig. 3). The temporal resolution of the time series is 10 days and spatial resolution cross-shelf is $4 \mathrm{~km}$. Pigment concentrations from winter months of uncertain satellite atmospheric correction in the four higher latitude regions are masked out.

enriched coastal water, in 1979 the maximum is in early July and extends $160 \mathrm{~km}$ offshore, in 1980 the maximum is centered in September and reaches $100 \mathrm{~km}$ offshore, in 1981 it is in early August and reaches $200 \mathrm{~km}$ offshore, in 1982 it is in mid-June and reaches $180 \mathrm{~km}$ offshore and in 1983 it is in early June reaching only $80 \mathrm{~km}$ offshore. The anomalies primarily reflect this interannual 

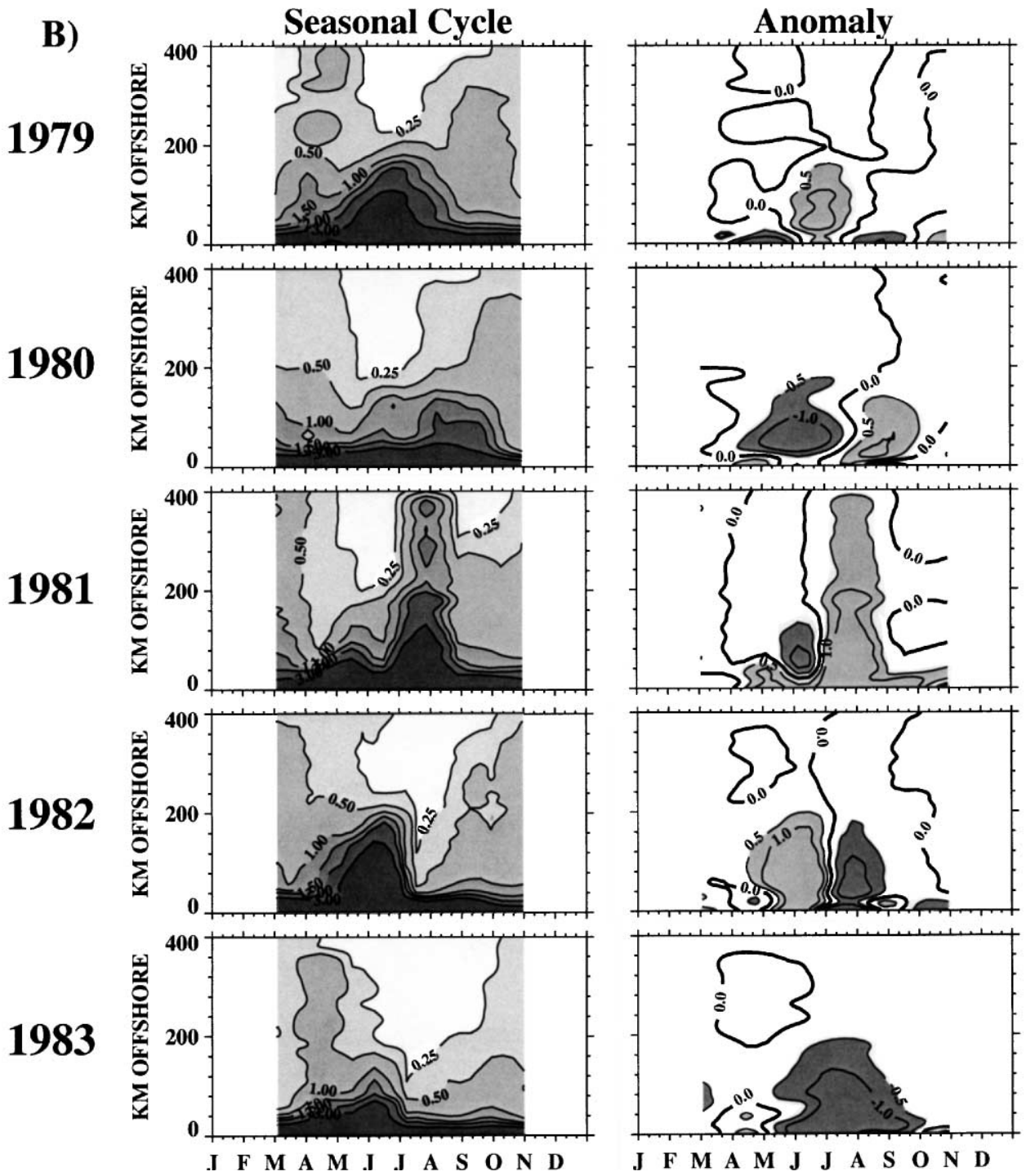

Fig. 2. (Continued)

variability in the timing and offshore extent of the major pigment episode. In 1983, however, strong negative anomalies $\left(<-0.5 \mathrm{mg} \mathrm{m}^{-3}\right)$ are present from mid-May until the beginning of October with a maximum offshore extension of $200 \mathrm{~km}$ all through July.

Off Northern California (37.8-40.4 ${ }^{\circ}$, Fig. 2c), two maxima in cross-shelf pigment extension are evident in each year, although in 1982 the second peak is strongly reduced and only evident within $80 \mathrm{~km}$ of the coast. The timing of the second peak is relatively consistent between years, occurring in September in each year except 1981 (mid-July). The earlier peak is considerably more variable both in timing within the season and in the actual concentrations which extend offshore. 

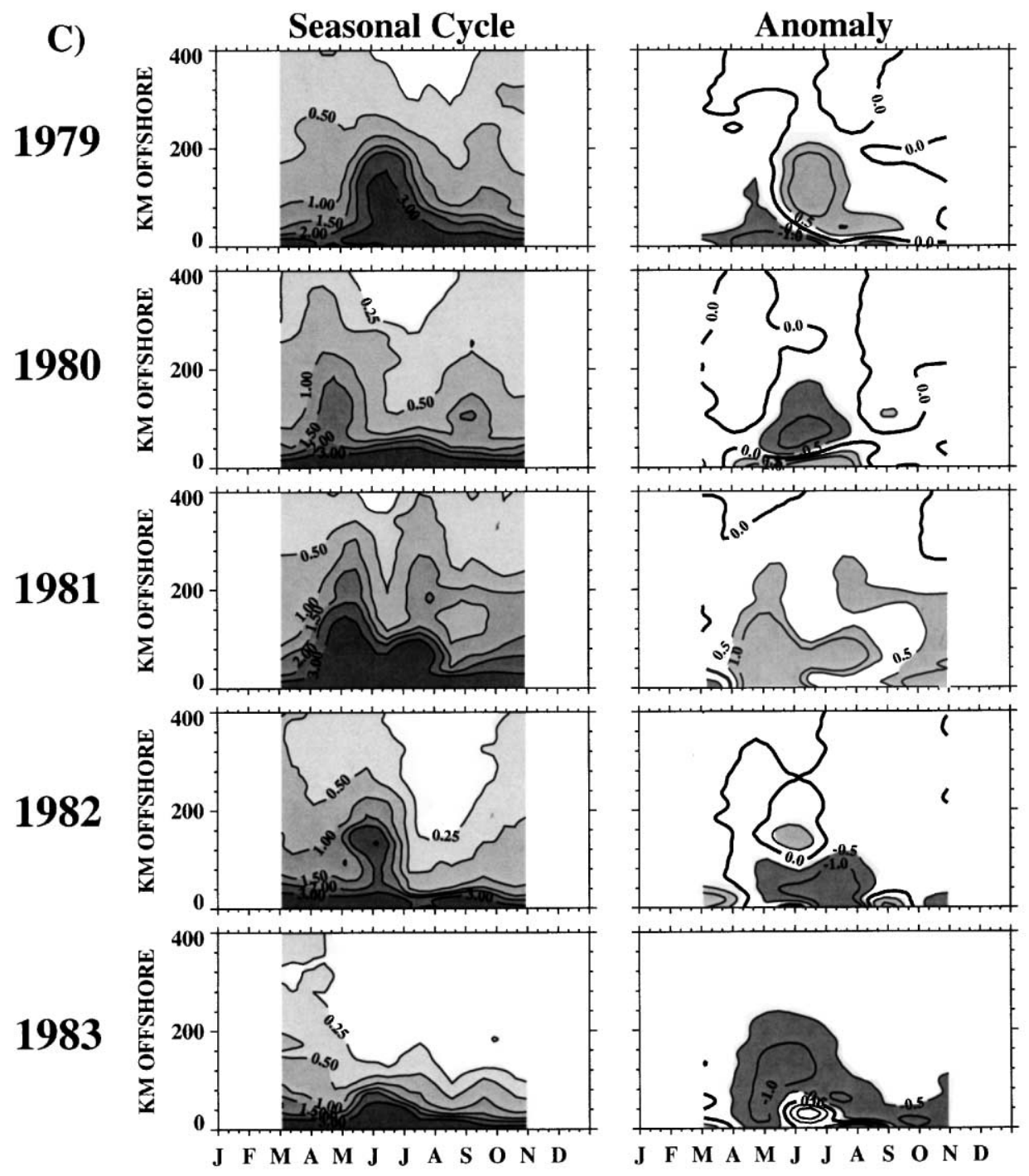

Fig. 2. (Continued)

This early peak (using the $2.0 \mathrm{mg} \mathrm{m}^{-3}$ isoline as a metric) begins in May in 1979, 1982 and 1983, but earlier (March-April) in 1980 and 1981. Pigment patterns remain most closely associated with the coast in 1983 , with the $1.0 \mathrm{mg} \mathrm{m}^{-3}$ isoline extending a maximum of $100 \mathrm{~km}$ offshore briefly in June. In all other years, concentrations of at least $1.0 \mathrm{mg} \mathrm{m}^{-3}$ extend over $200 \mathrm{~km}$ offshore at some point during the season. These patterns are consistent with those shown by Thomas and Strub (1990), who contrasted 30-day periods in spring with those of summer to show elevated pigments more closely associated with the coast in summer. The two maxima in the season are also consistent with the seasonal development of filament length investigated by Abbott and Barksdale (1991). The anomalies reflect differences in the timing of the major pigment cross-shelf extensions, 

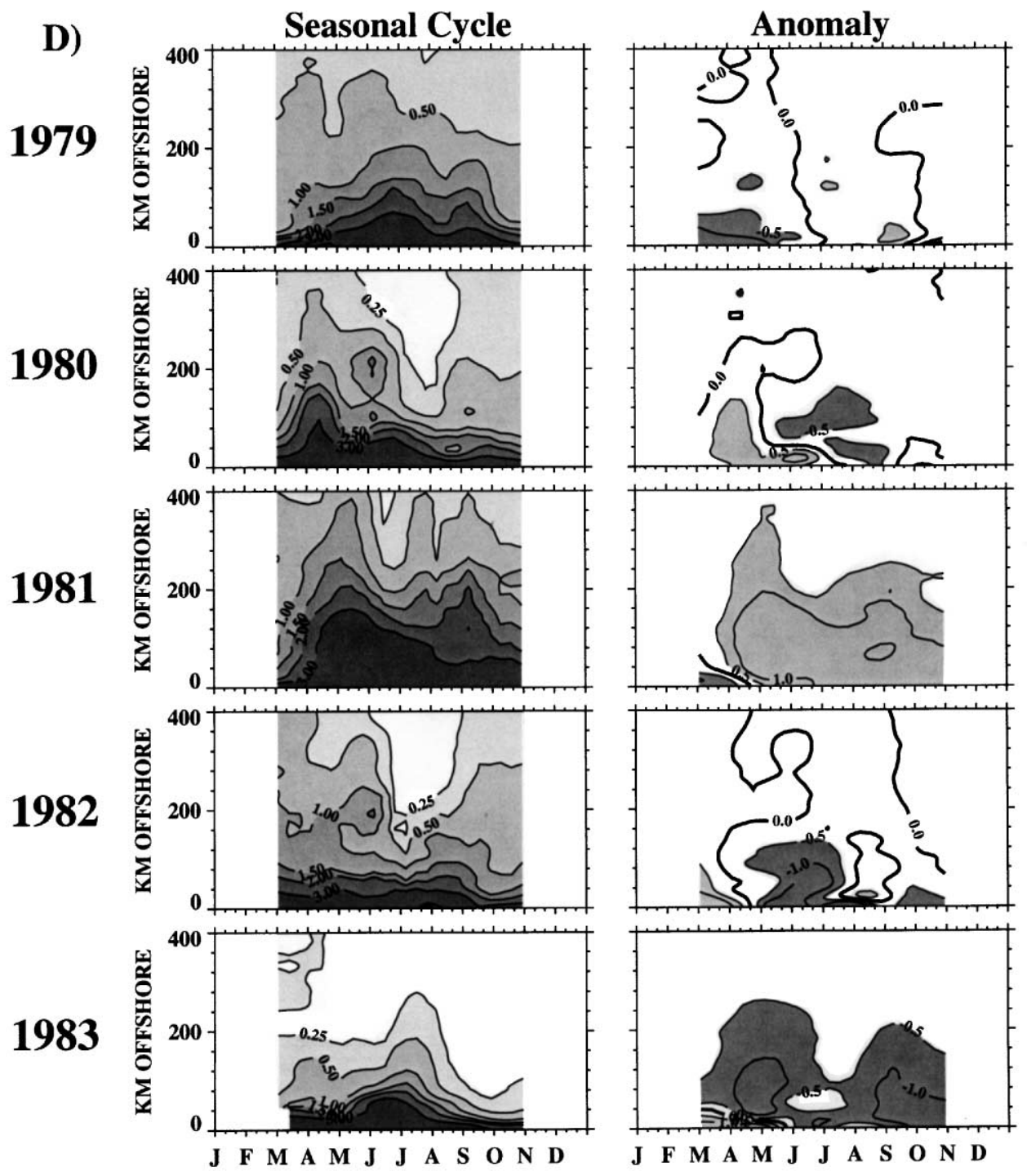

Fig. 2. (Continued)

with strong positive anomalies in June 1979 in the region 40-200 km offshore and throughout much of 1981 extending offshore over $240 \mathrm{~km}$. The most extensive period of negative anomalies occurs in 1983. In this year, the $-0.5 \mathrm{mg} \mathrm{m}^{-3}$ anomaly extends from the coast to over $200 \mathrm{~km}$ offshore in May and June, except in the zone within $100 \mathrm{~km}$ of the shore.

Cross-shelf patterns of the 1.0 and $1.5 \mathrm{mg} \mathrm{m}^{-3}$ isolines off Central California $\left(34.5-37.8^{\circ} \mathrm{N}\right.$, Fig. 2d) show three seasonal maxima in 1979, 1980 and 1981 and two in 1982 and 1983. Concentrations greater than $1.0 \mathrm{mg} \mathrm{m}^{-3}$ begin to expand offshore in late March in each year except 1982, with maximum and most sustained offshore extension of elevated concentrations $\left(>2.0 \mathrm{mg} \mathrm{m}^{-3}\right)$ in 1981 and minimum in 1983 . Using the $2.0 \mathrm{mg} \mathrm{m}^{-3}$ isoline as a metric, seasonal 

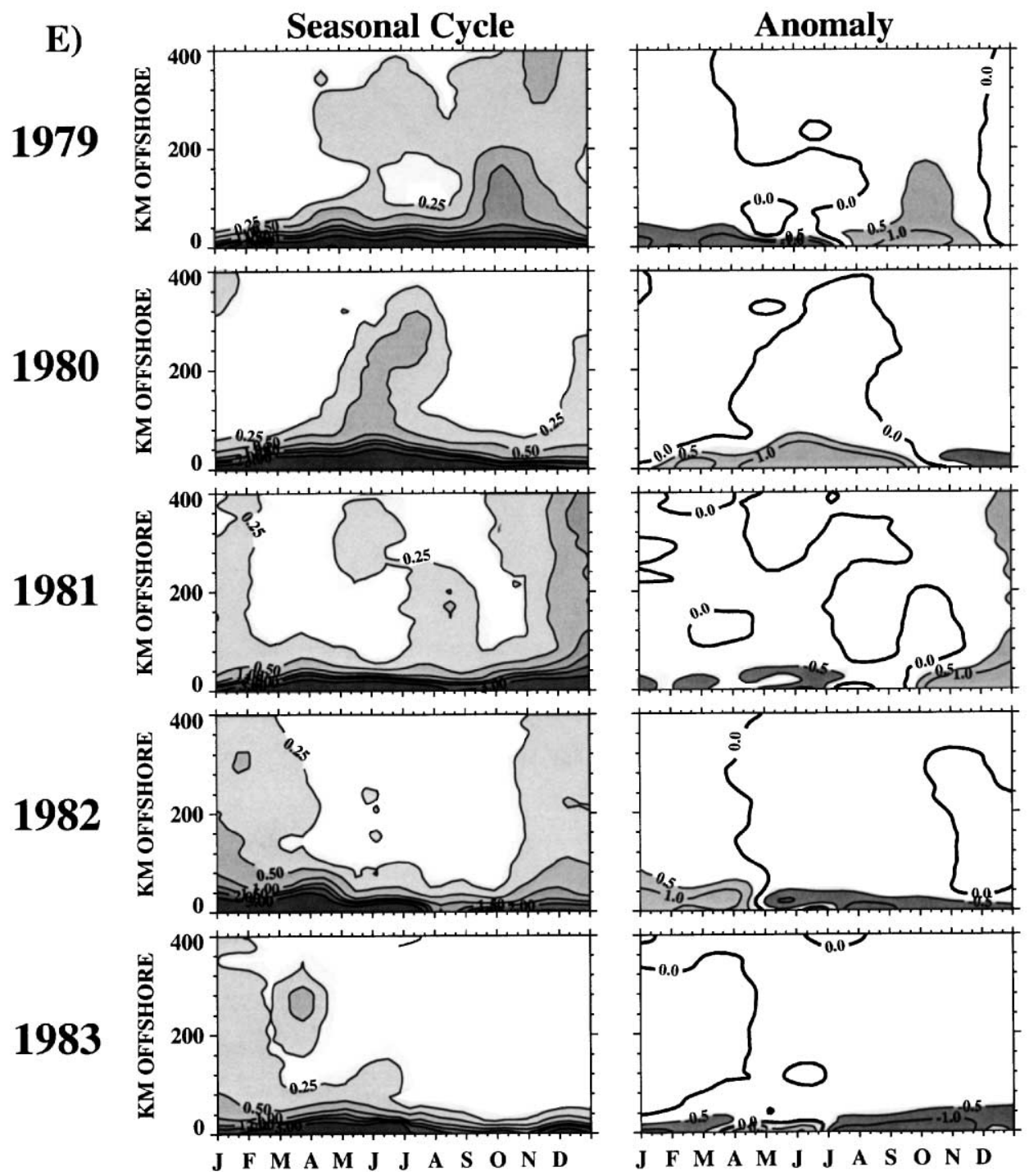

Fig. 2. (Continued)

maxima in cross-shelf distribution of elevated coastal concentrations have considerable interannual variability: late June in 1979, early April in 1980, early May in 1981, late April in 1982 and late June in 1983. This variability can be viewed as interannual differences in the relative strength of a mid-summer peak, as 1979, 1980 and 1983 all have peaks in late June. Positive anomalies are dominated by high pigment concentrations in 1981 which persist throughout the year and by their offshore extension to over $350 \mathrm{~km}$. The strongest negative anomalies are those in 1983 which persist throughout the entire observation period, extending from $40 \mathrm{~km}$ to over $240 \mathrm{~km}$ offshore. 

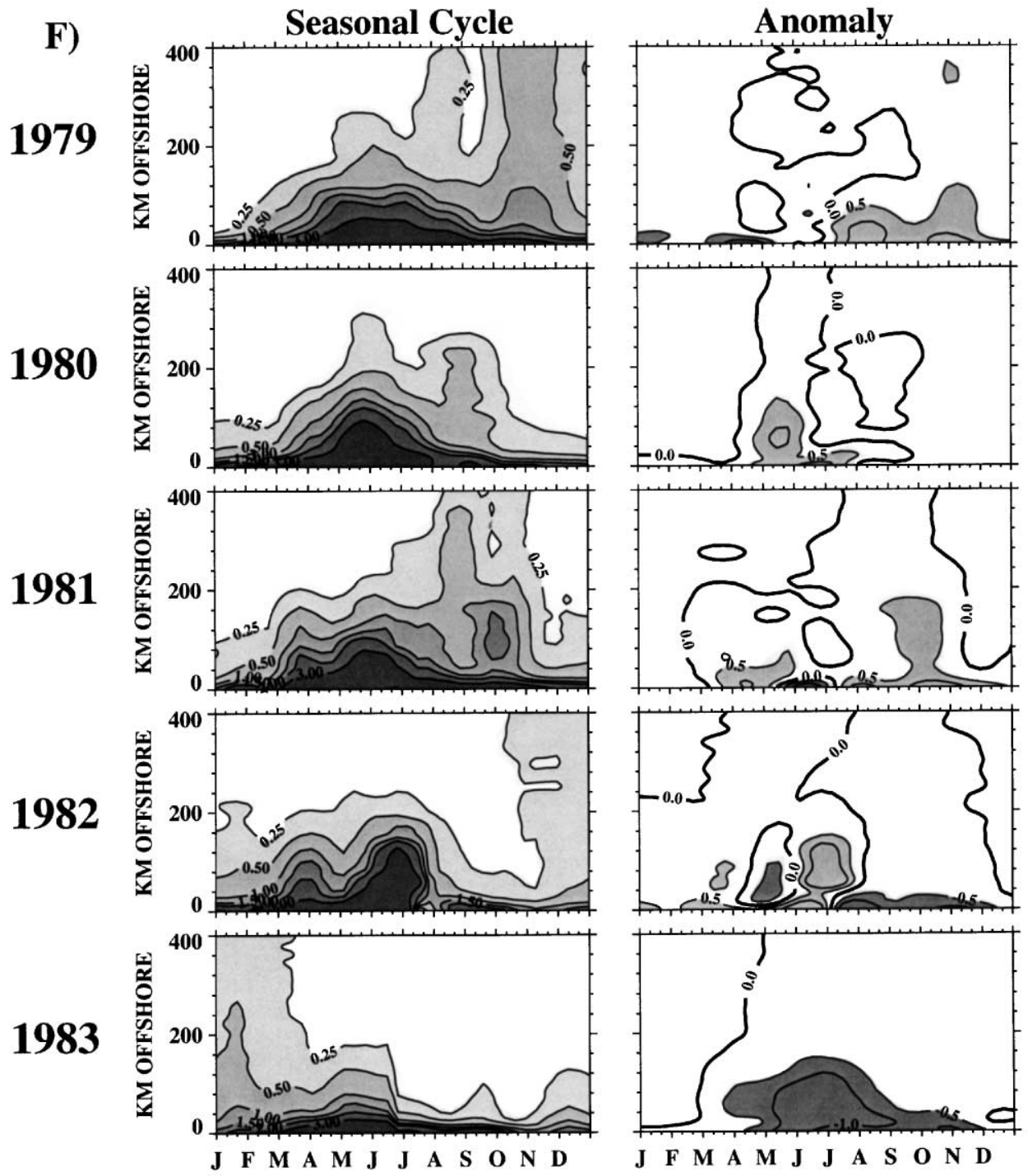

Fig. 2. (Continued)

The full seasonal cycle is shown for the two lowest latitude regions (Figs. 2e and f) where elevated pigments do not extend as far offshore as those at higher latitudes. Off Northern Baja $\left(29.4-32.5^{\circ} \mathrm{N}\right)$, pigment concentrations greater than $2.0 \mathrm{mg} \mathrm{m}^{-3}$ do not extend more than $50 \mathrm{~km}$ offshore in any season of the five-year study period. Concentrations greater than $0.5 \mathrm{mg} \mathrm{m}^{-3}$ reach over $100 \mathrm{~km}$ from shore during only three periods: fall 1979 (September-October), mid-summer in 1980 (June-July) and winter 1981-82 (December-January). Positive anomalies in the region greater than $50 \mathrm{~km}$ offshore are dominated by these offshore extensions of elevated pigment. Within $50 \mathrm{~km}$ of shore, the most extended periods of strong positive anomalies $\left(>1.0 \mathrm{mg} \mathrm{m}^{-3}\right)$ are 

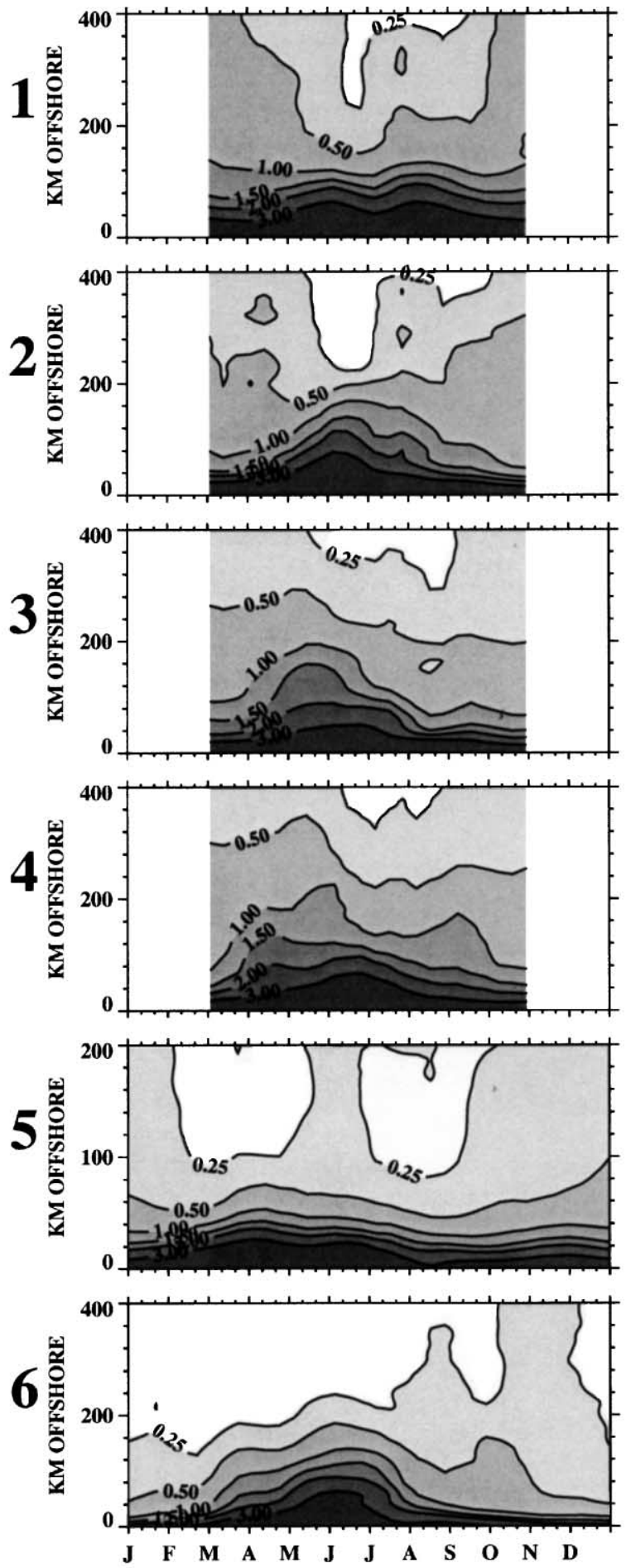

Fig. 3. Climatological CZCS cross-shelf pigment $\left(\mathrm{mg} \mathrm{m}^{-3}\right)$ distributions in each study region, calculated as the five-year (1979-83) mean at each location. Suspect winter concentrations from higher latitudes are not included. Note change of cross-shelf scale used on Region 5 (Northern Baja), to assist visualization of the seasonal cycle. 
in 1980 (from February through mid-September) and in 1981-82 (from October through early April). An extended period of negative anomalies begins in May 1982 and continues until the end of the observation period in December 1983 with a brief relaxation in April-June 1983.

Along the southern Baja coast $\left(22.9-27.9^{\circ} \mathrm{N}\right.$, Fig. 2f), elevated coastal pigment concentrations $\left(>2.0 \mathrm{mg} \mathrm{m}^{-3}\right)$ extend offshore to at least $100 \mathrm{~km}$ in all years except 1983 . Maximum cross-shelf extension of these concentrations occurs in May-early June in each year except 1982 (late June). There is evidence of two pulses in offshore extension early in the season during 1981 and 1982, with the earliest increase occurring in March and the second occurring in MayJune. A late season increase in offshore $(>200 \mathrm{~km})$ concentrations is evident in 1979, 1980 and 1981, but with quite different timing (November, September and September-October respectively). The largest positive anomalies reflect differences in the timing of the late season increase in 1979 and 1981, and the delayed mid-summer maximum in 1982. In a pattern similar to that observed off northern Baja, an extended period of negative anomalies begins in the nearshore region (within $40 \mathrm{~km}$ ) in mid-1982 and continues into December 1982. There is a relaxation of these anomalies in winter January-March) but then they begin again in April 1983 and continue in the nearshore region until December 1983. The anomalies in 1983 reach maximum strength (stronger than $-1.0 \mathrm{mg} \mathrm{m}^{-3}$ ) in late May through August and extend over $100 \mathrm{~km}$ offshore in June-July.

Dominant patterns of time/space variability within these data were extracted using empirical orthogonal functions (EOFs). The EOF modes summarize and condense the cross-shelf pigment distributions into a series of spatial patterns, each with an associated time series which describes the time-varying strength of the pattern. Winter data (November-February) in the four higher latitude regions were not included in the calculations. In each latitudinal region, the first two modes explain approximately $90 \%$ or more of the total cross-shelf phytoplankton pigment variance (Fig. 4) and only these are presented. The dominant mode in each region captures strong pigment concentration variability very close (within approximately $50 \mathrm{~km}$ ) to shore, decreasing rapidly from the location immediately adjacent to the coast to zero approximately $100 \mathrm{~km}$ offshore. This mode quantifies temporal variability in the very nearshore zone which is not evident in the contour plots. Their interpretation, however, must be made with caution. The region close to shore is known to contain biases in the CZCS data due to such factors as suspended sediment and saturation of the signal by high reflectances. The spatial patterns in the first mode are remarkably consistent over the latitudinal extent of the study area, with largest cross-shelf extent off southern Baja, and minimum off northern Baja. The time series associated with the first EOF mode shows a consistent pattern of maximum strength in mid-summer across all years and regions, but comparisons between years show no consistent pattern of interannual variability across all six regions. Within seasons, strong variability is indicative of episodic events modulating nearshore pigment concentrations. Within these time series, two maxima within a seasonal cycle are evident in many of the years at the four higher latitude regions, one early in the season, followed by a mid-summer decrease and then the second maximum late in the season. The second EOF mode of each region captures a more complex spatial pattern of pigment concentrations seaward of the region immediately adjacent to the coast. Maximum concentrations are present in a zone between 50 and $100 \mathrm{~km}$ offshore, followed by a gradient to an offshore region of relatively low spatial variability and low concentrations. The gradient separating offshore low variance from the zone of higher variance immediately offshore of the coastal zone varies in strength and 


\section{Region 1}

Mode 1, $\quad 86 \%$

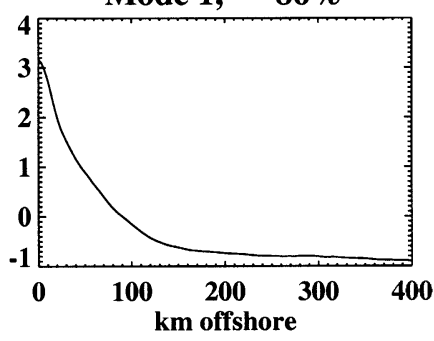

Mode 2, $\quad 8 \%$

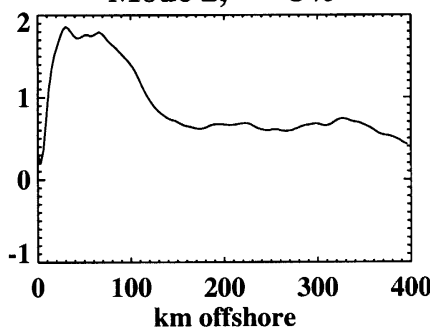

Time Series

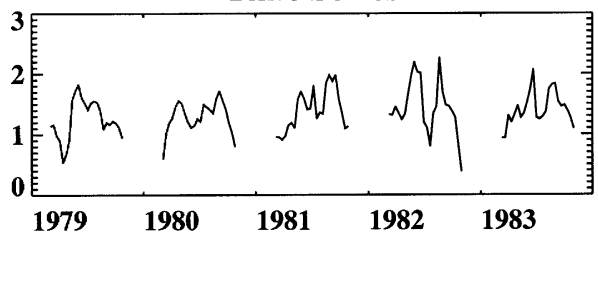

Mode 1, $\quad 76 \%$

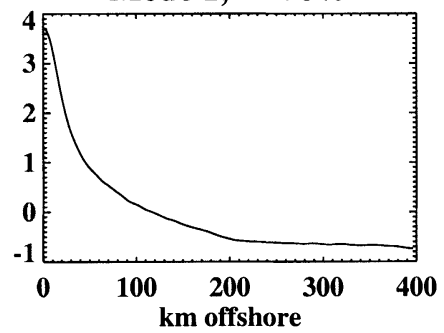

Mode 2, $\quad 18 \%$

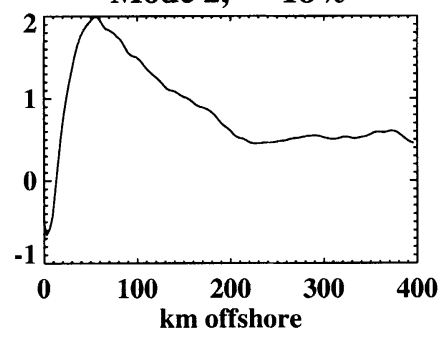

Time Series

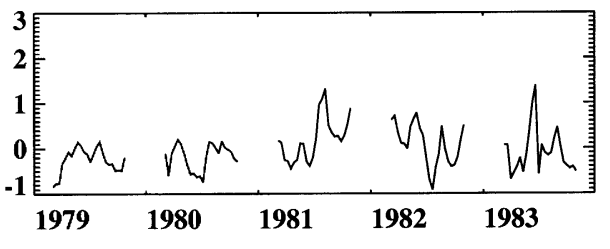

\section{Region 2}

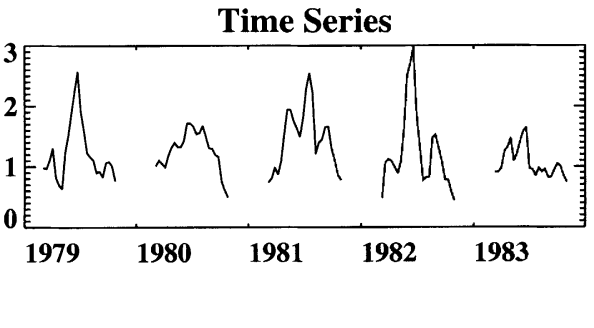

Time Series

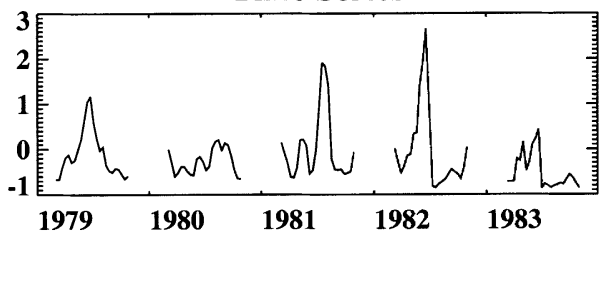

Fig. 4. The two dominant modes of the EOF decomposition of the cross-shelf pigment time series for each of the six study regions showing the spatial pattern and the amplitude time series associated with each. The variance explained by each mode is shown as a percentage of the total variance associated with each region. 


\section{Region 3}
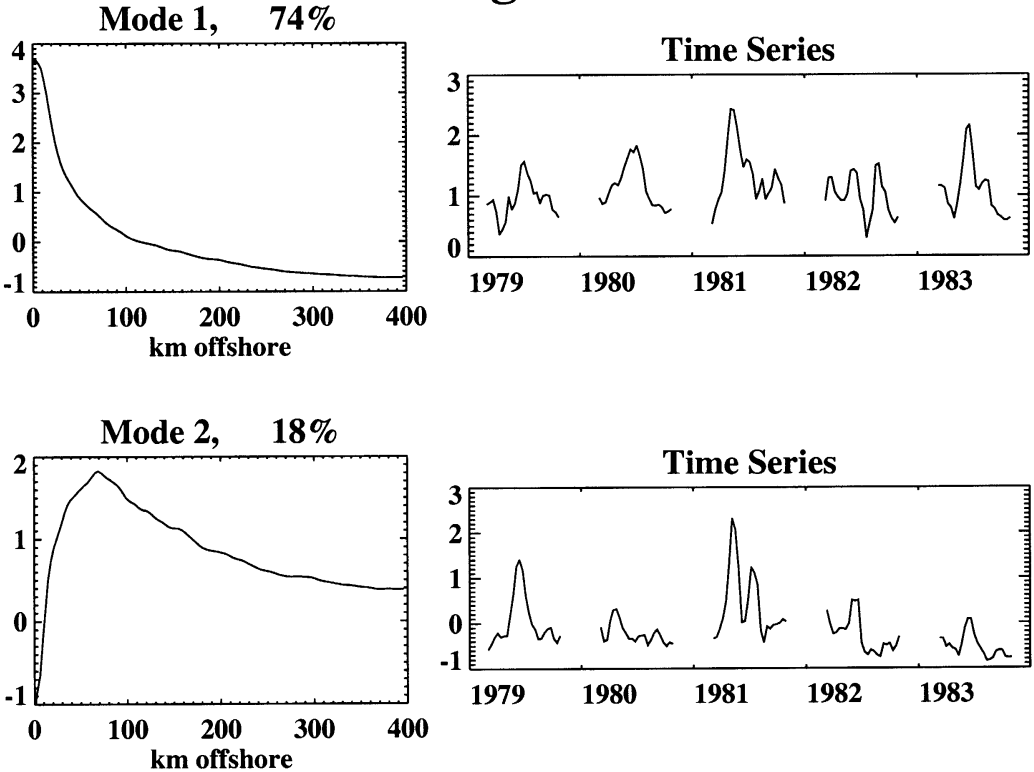

\section{Region 4}

Mode 1, $\quad 78 \%$

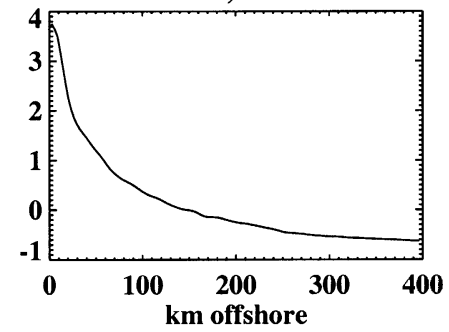

Mode 2, $16 \%$

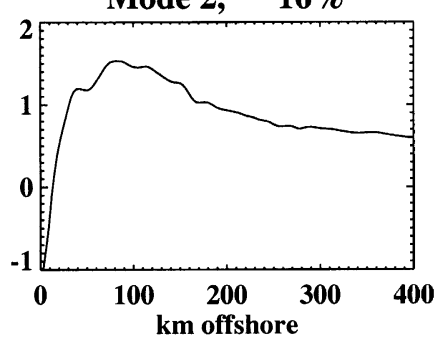

Time Series

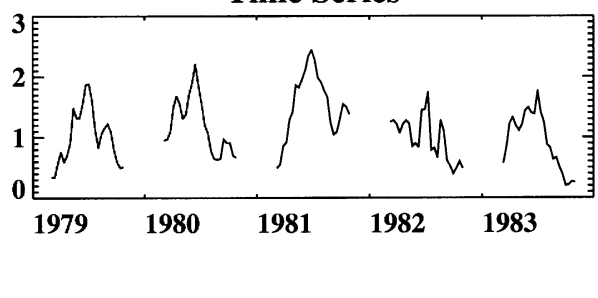

Fig. 4. (Continued) 


\section{Region 5}

Mode 1, $\quad 90 \%$

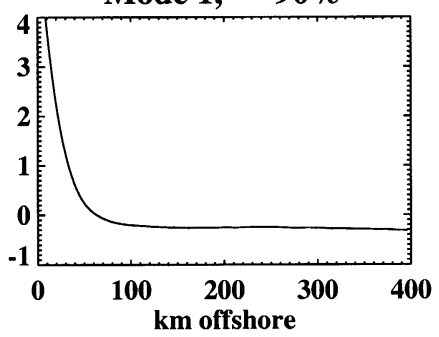

Mode 2, $6 \%$
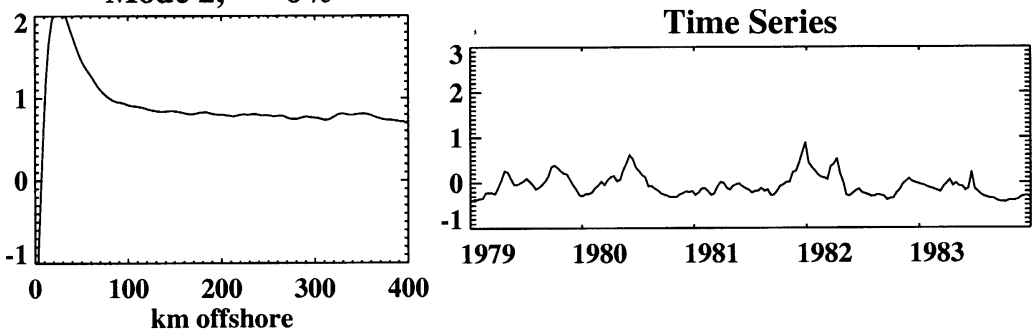

Time Series

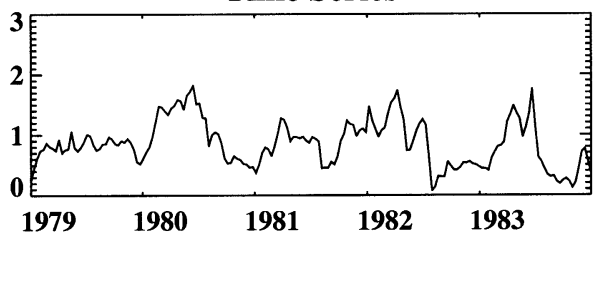

Mode 1, $\quad \mathbf{8 0} \%$

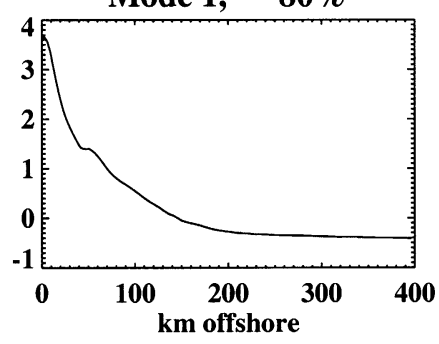

Mode 2, $\quad 14 \%$

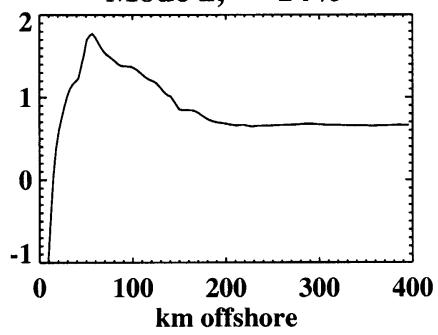

\section{Region 6}
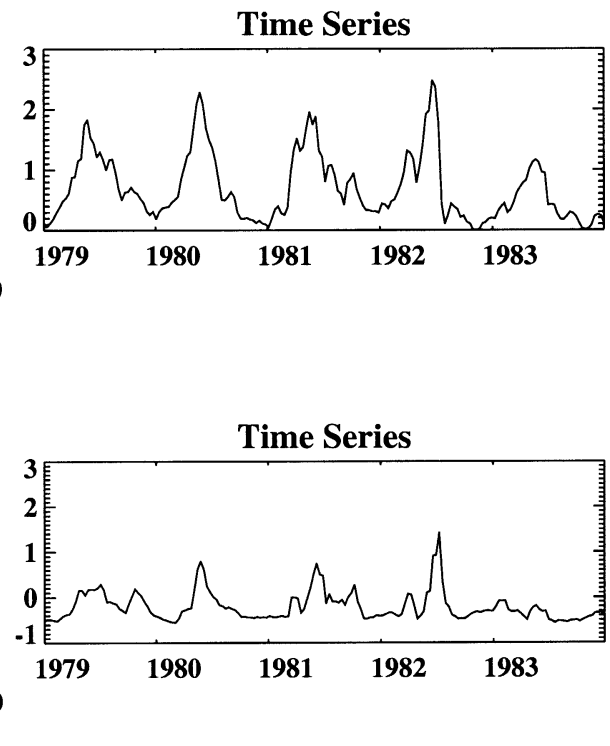

Fig. 4. (Continued) 
location between regions: relatively strong in Regions 1 and 2 and located 75-150 and 50-200 km offshore respectively, relatively weak in Regions 3 and 4 and located $75-250 \mathrm{~km}$ and $90-250 \mathrm{~km}$ offshore respectively, strong and located between 25 and $75 \mathrm{~km}$ offshore, immediately seaward of the coastal peak (mode 1) in Region 5, and spread between 50 and $150 \mathrm{~km}$ offshore in Region 6. Comparisons between years and regions show that a more consistent pattern of interannual variability is captured in this second mode. With the exception of the Pacific Northwest (Fig. 4a) the time series of the second mode is relatively weak throughout 1983. This indicates that most of the latitudinally consistent interannual variability in the California Current system occurs in pigment concentrations offshore and not in the zone immediately adjacent to the coast.

Anomalous phytoplankton patterns during 1983 are not unexpected. The strong El Niño of 1982-83 produced anomalous hydrographic characteristics throughout the California Current System (e.g. Simpson, 1983; Huyer and Smith, 1985; Rienecker and Mooers, 1986). The dominant effect was a deepening of the pycnocline, which decreased the effectiveness of any vertical motions induced by wind forcing, and increased the isolation of surface layers from nutrient rich subsurface water (Lynn et al., 1995). Previous analyses of CZCS data show reduced concentrations during El Niño conditions, consistent with field observations of surface chlorophyll (Millan et al., 1996). Fiedler (1984) contrast images from 1982 and 1983 to show reduced spatial extent of elevated concentrations in 1983 within the Southern California Bight. Thomas and Strub (1989) show that pigment concentrations in 1983 remained low after the spring transition to upwelling-favorable winds off Northern California. Strub et al. (1990) show that the largest non-seasonal anomaly in pigment patterns in the 1979-86 CZCS data set occurs as low concentrations during the 1982-83 period with maximum amplitude between $35^{\circ} \mathrm{N}$ and $45^{\circ} \mathrm{N}$. Abbott and Barksdale (1991) show that concentrations off Central California are lower than average in 1983, especially in spring, and that the lengths of filaments of high pigment concentration were strongly reduced in 1983 between Cape Mendocino and Point Conception (our Regions 3 and 4). Patterns in Figs. 2 and 4 quantify differences in the largescale cross-shelf pigment pattern associated with the 1982-83 El Nino and its latitudinal variability.

\subsection{Alongshore wind stress}

Extensive analyses of field data during the CTZ Experiment (Brink and Cowles, 1991) suggest that the large-scale, cross-shelf pattern of phytoplankton pigment concentrations observed here will be a result of the combined influences of the strength, timing and persistence of coastal upwelling induced by equatorward alongshore wind stress, the persistence of local mesoscale dynamics and the cross-shelf position of the main current jet of the California Current. Thomas and Strub (1989) show that the timing and strength of both wind mixing and alongshore wind stress have an influence on patterns of pigment distribution in the spring, at least at latitudes between $33^{\circ} \mathrm{N}$ and $41^{\circ} \mathrm{N}$. They point out that in offshore regions $(>300 \mathrm{~km})$, spring increases in pigment concentration are most closely related to vertical processes resulting from mixing rather than alongshore wind stress. General characteristics of the alongshore wind stress over the California Current system are well known (Bakun and Nelson, 1991; Strub et al., 1990). Relationships between wind and phytoplankton pigment patterns off Central California are 
shown by Abbott and Barksdale (1991) and between wind and satellite SST patterns off northern California by Kelly (1985). Wind is upwelling favorable throughout the year at low latitudes (south of approximately $33^{\circ} \mathrm{N}$ ). With increasing latitude, winter downwelling-favorable winds become stronger and occupy an increasing proportion of the seasonal cycle, switching to upwelling favorable over the summer. Maximum upwelling-favorable wind stress is present off northern California. Here we examine concurrent alongshore wind stress measurements for seasonal and interannual characteristics consistent with the observed patterns of large-scale crossshelf pigment distribution evident in Fig. 2. Attention is focussed on patterns in the relatively high (2.0-3.0 $\mathrm{mg} \mathrm{m}^{-3}$ ) concentrations nearshore, which might be most strongly related to local upwelling-favorable wind forcing.

The general wind forcing characteristics described above are evident in Fig. 5 which shows the time series in each study year of alongshore wind stress at each latitudinal region and also the anomalies from the five-year mean to highlight interannual differences. Over the five-year study period, alongshore wind stress in the Pacific Northwest region exhibits considerable interannual variability in both the date when upwelling starts and the intensity with which it switches and persists. Years when sustained upwelling-favorable winds arrive relatively late (1979, 1981 and 1983) (Fig. 5a) are also years when the initial spring increase in cross-shelf extension of the highest $\left(1.5-2.0 \mathrm{mg} \mathrm{m}^{-3}\right)$ coastal pigment concentrations is relatively late (mid-May) (Fig. 2a). In both 1980 and 1982, both sustained upwelling winds and pigment patterns develop earlier (late April). In 1980 and 1981, strongest upwelling winds occur relatively late in the season (August) consistent with the years in which coastal elevated pigment concentrations $\left(2.0-3.0 \mathrm{mg} \mathrm{m}^{-3}\right)$ also exhibit maximum cross-shelf extension in August. Farther south in the Cape Blanco-Cape Mendocino region, the strongest consistent similarities are evident in the timing of the seasonal maximum in alongshore wind stress and pigment patterns. In years when the wind maximum is relatively late in the season (1980 and 1981) (Fig. 5b), seasonal maxima in coastal concentrations and offshore extension are also late (Fig. 2b). When wind forcing is earlier in the year, the pigment maximum is also earlier $(1979,1982)$. Relationships between early season (spring) wind forcing and cross-shelf patterns, however, are not consistent. The year in which upwelling-favorable winds develop latest in the season (midApril, 1982), does not show later temporal development of patterns than other years. Off both northern and central California, the two years when relatively strong upwelling-favorable winds begin early (1980 and 1981) (Figs. 5c and d) are the two years with the earliest increases in crossshelf pigment development (Figs. $2 \mathrm{c}$ and d). The two years when wind forcing is weak early in the season are the two years with delayed maxima in cross-shelf extension (1979 and 1982). The year with the maximum and most sustained seasonal alongshore wind stress (1981) in these regions is also the year in which maximum cross-shelf extensions of elevated $\left(2.0 \mathrm{mg} \mathrm{m}^{-3}\right)$ pigment concentration are present. In the northern Baja region, where upwelling-favorable winds occur year-round, maximum in the spring-early summer (Fig. 5e), the seasonal cycle in both wind forcing and cross-shelf pigment structure (Fig. 2e) is weakest. Consistent relationships between wind and pigment patterns between years are not evident. In the southern Baja region (Fig. 5f), the seasonal maximum in alongshore wind stress is also in spring-early summer but stronger than that off northern Baja. Although the seasonal peak in cross-shelf pigment patterns is also in the spring-early summer (Fig. 2f), consistent specific relationships to the wind forcing are not obvious. 


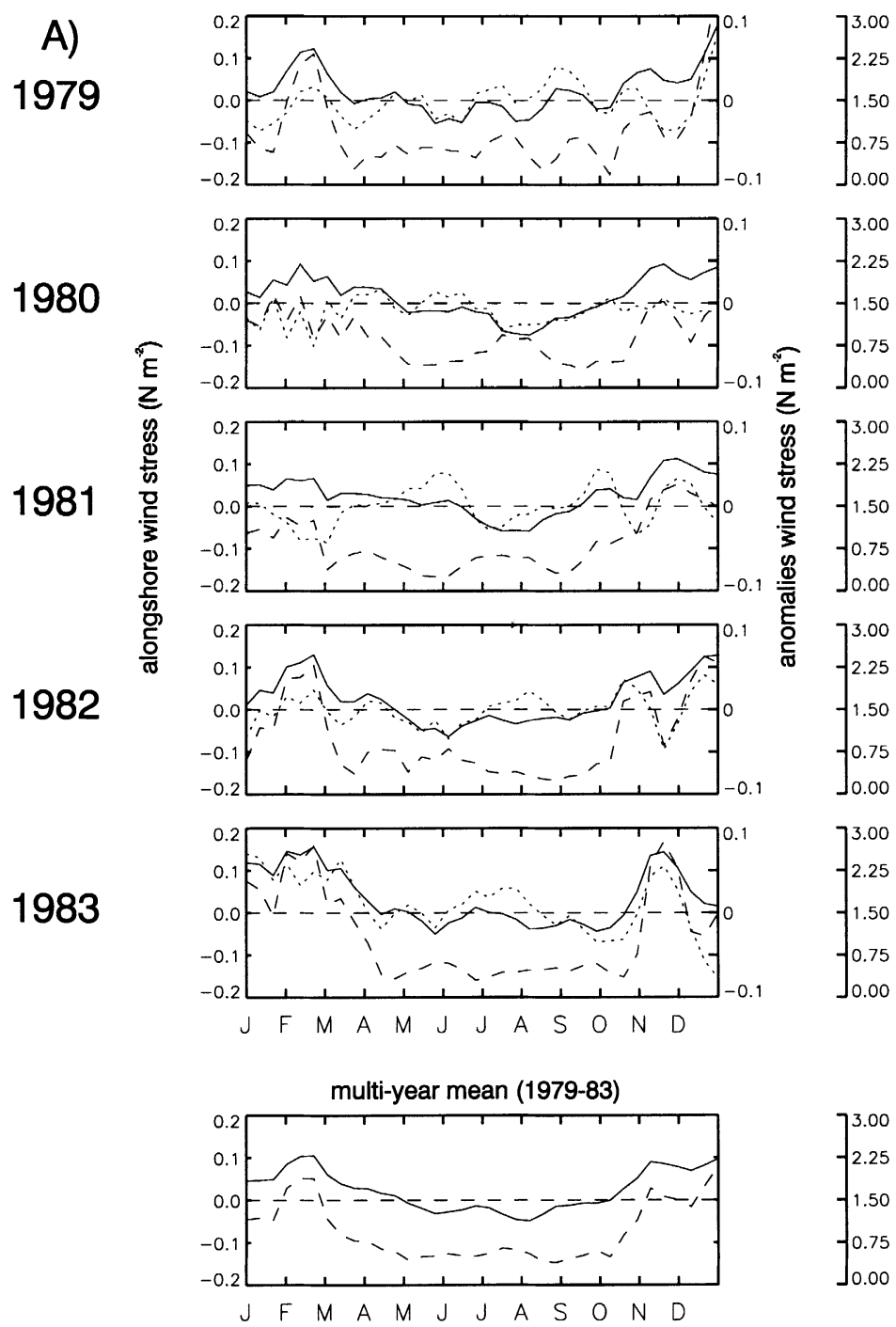

Fig. 5. Alongshore wind stress (solid line) and strength of wind mixing (as $U^{* 3}$, dashed line) in each year in each of the six study regions, (a) Pacific Northwest, (b) Cape Blanco to Cape Mendocino, (c) Northern California, (d) Central California, (e) Northern Baja and (f) Southern Baja. Also shown are the alongshore wind stress anomalies from the fiveyear mean (dotted line) used in the cross-correlation with cross-shelf pigment metrics. Negative stress is equatorward and upwelling favorable. The five-year mean of both alongshore wind stress and $U^{* 3}$ is shown in the bottom plot.

\subsection{Pigment-wind forcing relationships}

The qualitative relationships between wind forcing and cross-shelf phytoplankton pigment patterns over the five-year study period discussed above were examined quantitatively using crosscorrelations. Pigment concentrations, similar to many biological signals, are not expected to be normally distributed (e.g. Campbell et al., 1995) and statistics which make this assumption need to be avoided. Cross-correlations between wind and pigment time series were calculated using the 

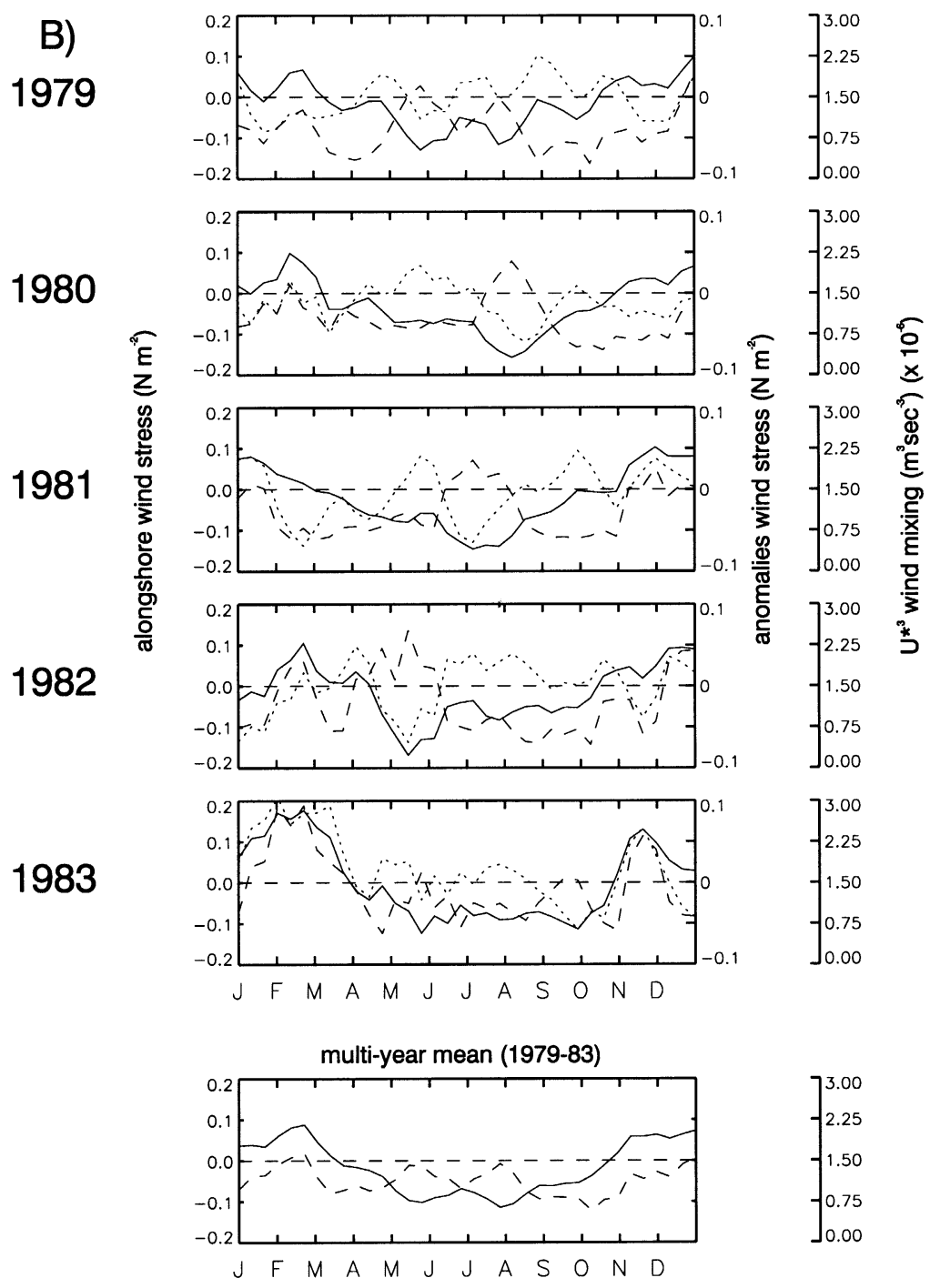

Fig. 5. (Continued)

non-parametric Spearman rank-order correlation coefficient which avoids assumptions about the underlying distribution of the data. Choice of this metric of correlation also reduces the weighting given to extreme outliers but does not conserve variance.

Eight time series, representing different metrics of cross-shelf pigment distribution, were subsampled from the 10-day image time series in each latitudinal region. The cross-shelf pigment metrics tested for correlation with local wind forcing were the time series of the two dominant EOF modes (shown in Fig. 4), the distance from shore (in $\mathrm{km}$ ) of the 1.0, 1.5, 2.0 and $3.0 \mathrm{mg} \mathrm{m}^{-3}$ isoline and the integrated pigment concentration within $50 \mathrm{~km}$ and within $100 \mathrm{~km}$ of shore (a visual representation of these latter six metrics is made in Fig. 2). Thomas and Strub (1989) and 


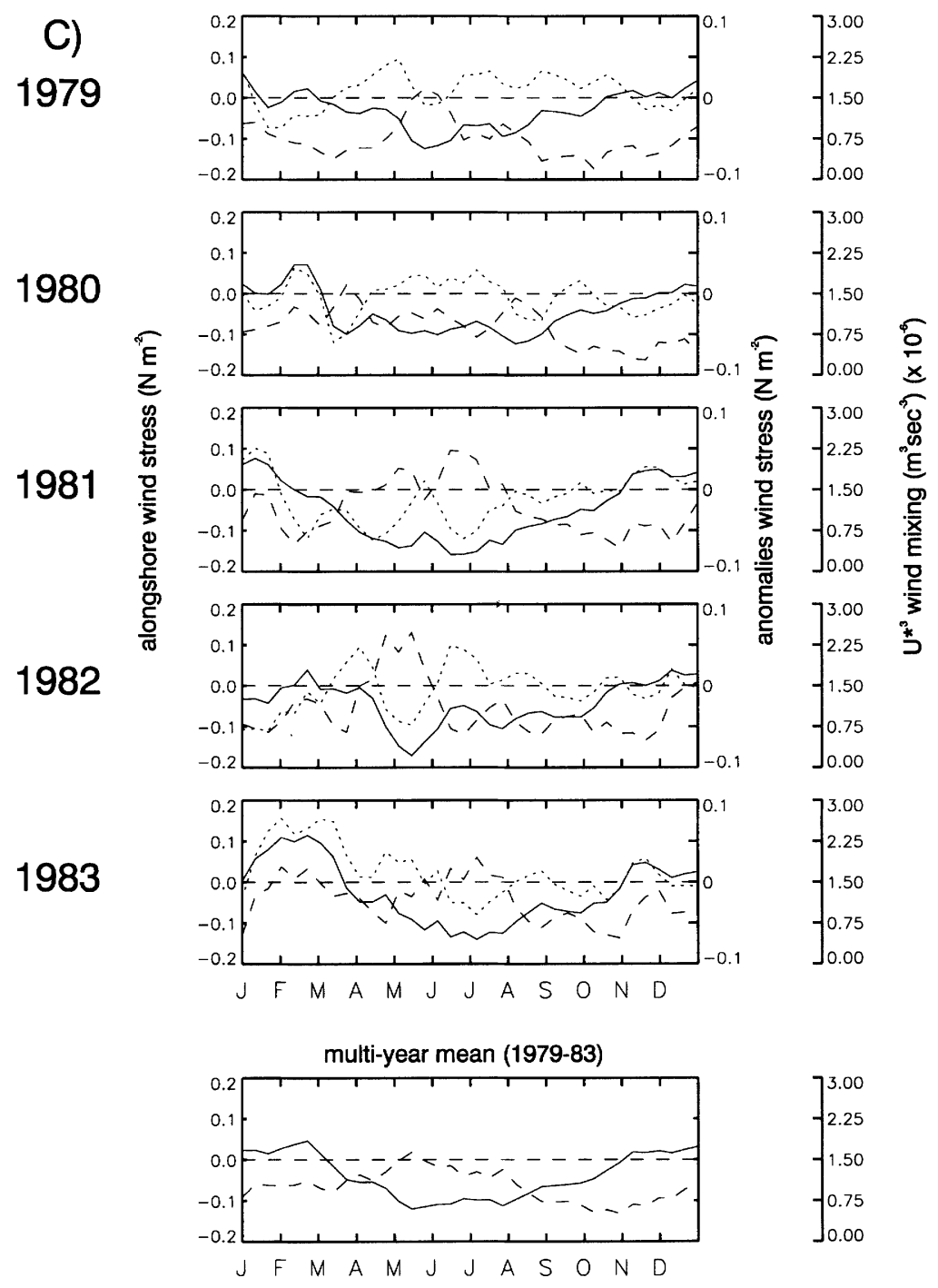

Fig. 5. (Continued)

Strub et al. (1990) show that both alongshore wind stress and the total amount of wind mixing may play a role in determining phytoplankton pigment temporal patterns. The cross-correlation of each pigment metric with the coincident time series of both alongshore wind stress and wind mixing (parameterized as $U^{* 3}$ ) was calculated. Visual examination of the time series of both wind and pigment shows a significant, but varying seasonal cycle in each year. To avoid spurious correlations due simply to similar seasonal cycles, the climatological (five-year) seasonal signal was calculated and removed from each and cross-correlations calculated on the non-seasonal signals (anomalies). This produced a matrix of 96 cross-correlation functions (six regions, two wind metrics, eight pigment metrics), each a function of temporal lag. Time series at the four highest latitude regions did not include data from the November-February period. Values of the 


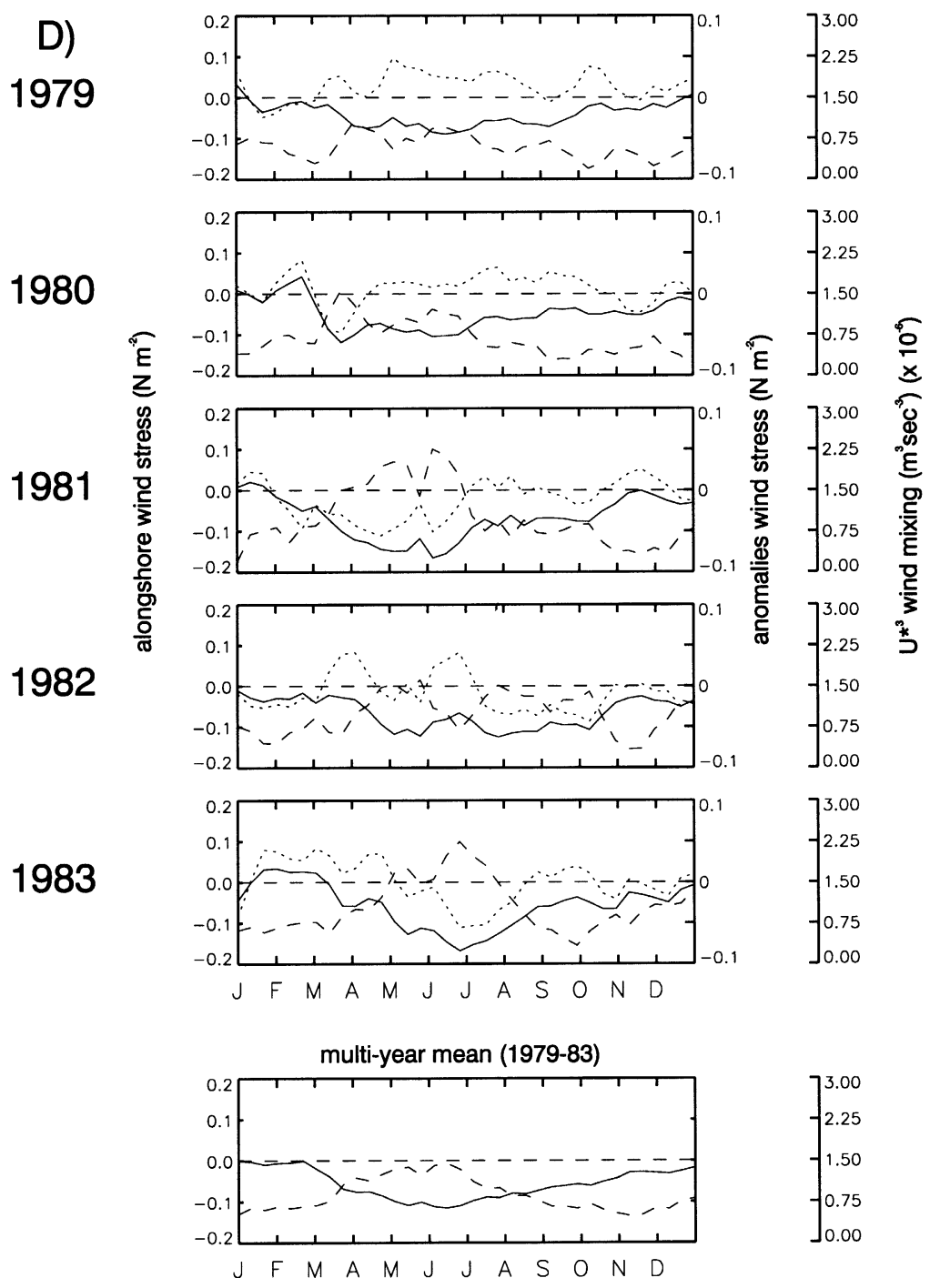

Fig. 5. (Continued)

Spearman rank-order correlation coefficient $\left(r_{s}\right)$ vary between -1 and 1. Significance of non-zero values is tested by calculating $t=r_{s}\left[(N-2) /\left(1-r_{s}\right)\right]^{0.5}$ (where $N$ is the number of data points) which is distributed approximately as a Student's distribution with $N-2$ degrees of freedom.

Results from the cross-correlation of wind and pigment for each latitudinal region are shown in Table 1. Presentation of the large correlation matrix is simplified by showing (a) only those portions of the correlation functions which were significant at the $90 \%$ level or greater and (b) only lags of 0,1 and 2 (10 day) periods (pigment follows wind forcing). Lags between -2 (pigment preceding wind) and 5 were examined, but negative lags produced very few and scattered significant $(90 \%)$ ) correlations, and the number and strength of significant correlations decreased dramatically at positive lags greater than 2 . Table 1 shows that significant correlations between 


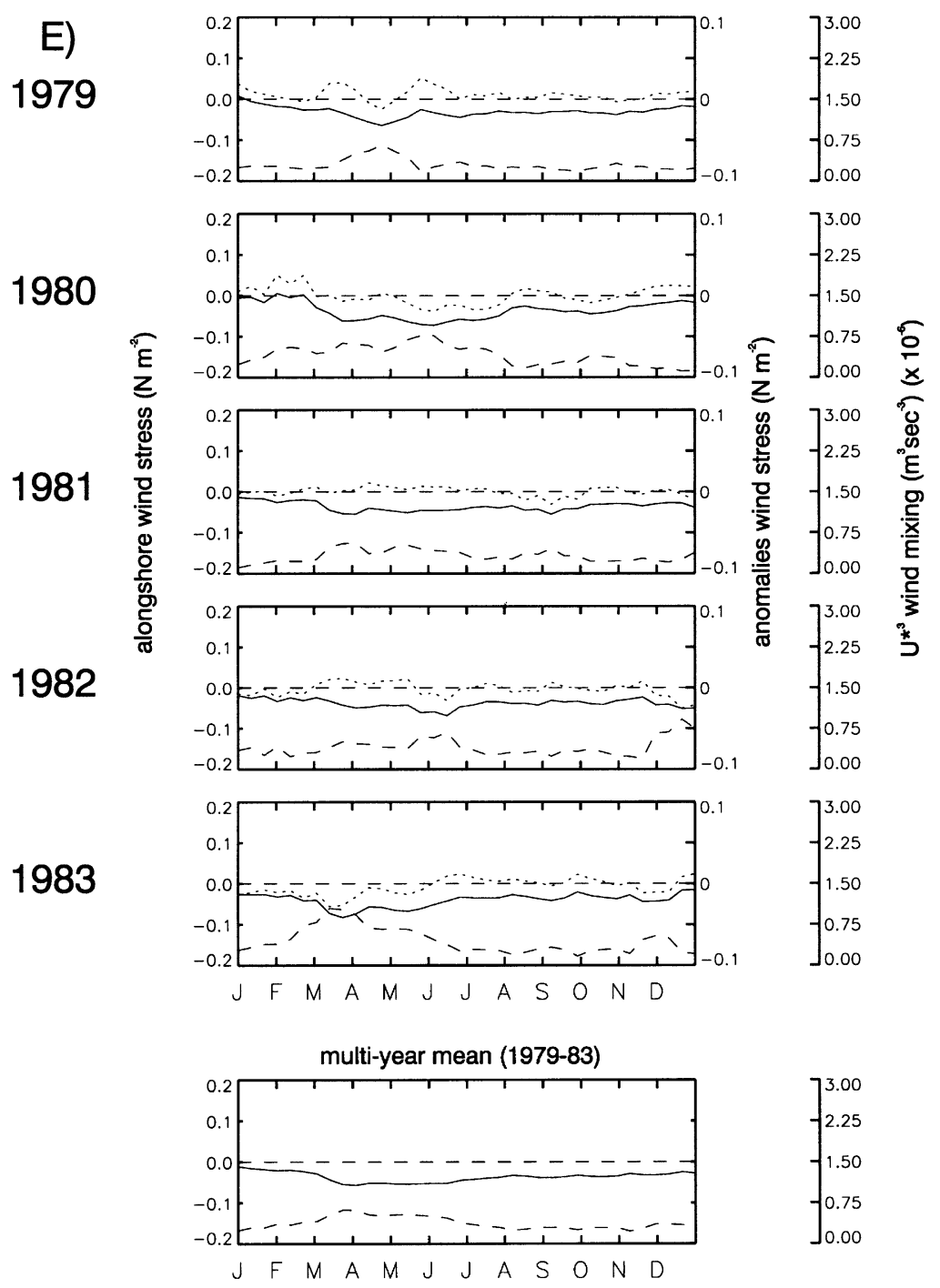

Fig. 5. (Continued)

satellite-measured cross-shelf pigment patterns and wind forcing exist at all six latitudinal regions. With the exception of two nearshore metrics off southern Baja, all significant correlations between pigment and alongshore wind stress are negative, meaning that large values for pigment metrics are associated with smaller (more negative, or upwelling favorable) wind stress values. Significant correlations with wind mixing $\left(U^{* 3}\right)$ are positive indicating that large pigment metrics are associated with increased wind mixing.

Relationships off Washington and northern Oregon (Region 1) are relatively weak and involve fewer pigment metrics than those off California and southern Oregon. With one exception, significant correlations are not present after a lag of 1 period with either wind metric and few 


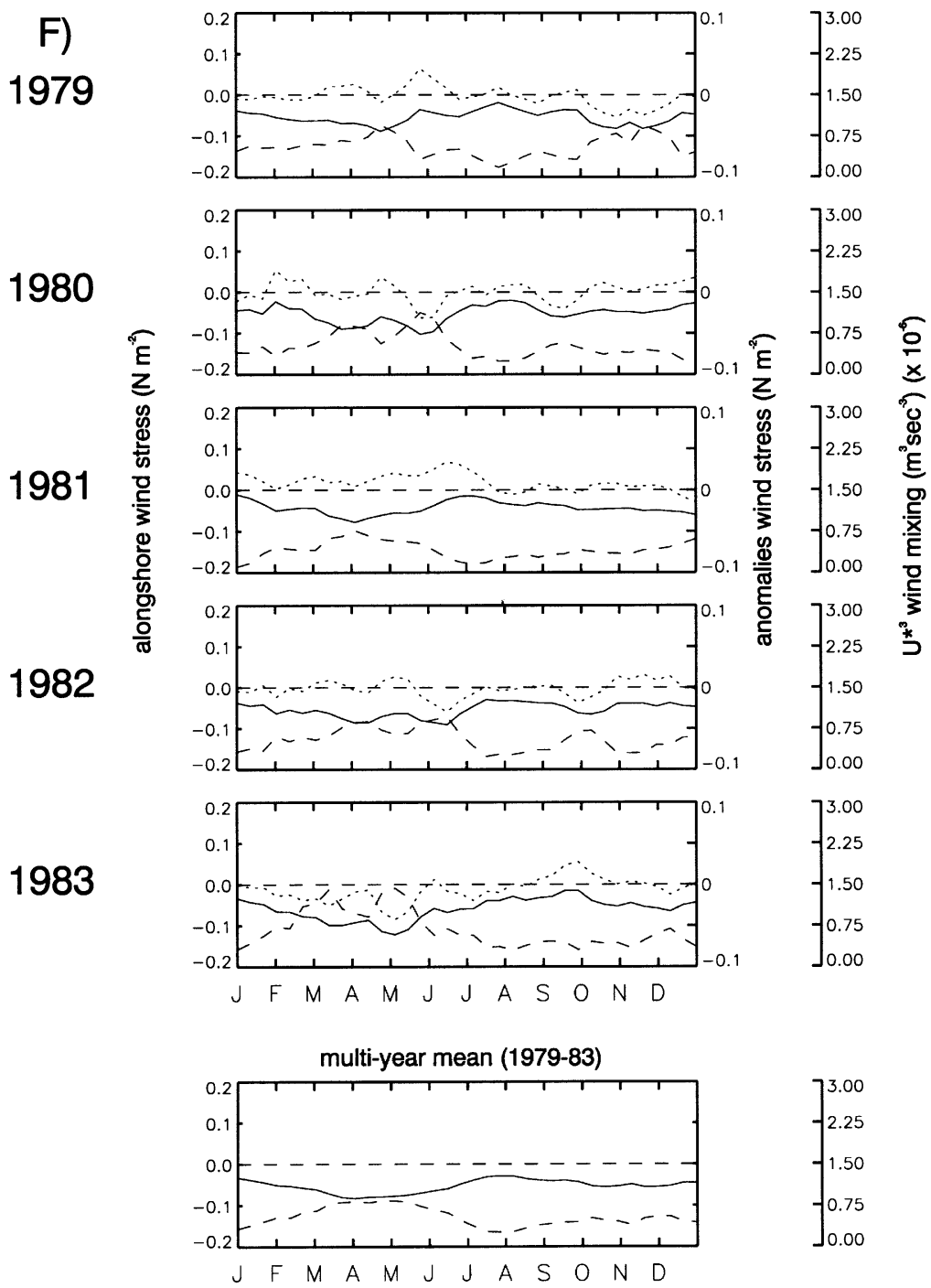

Fig. 5. (Continued)

relationships are evident between alongshore wind stress and pigment pattern metrics. This indicates that at the scales examined here, while cross-shelf pigment patterns at these latitudes might be responding on 10- and 20-day time scales to overall wind strength, they are poorly related to local alongshore winds. A complicating factor in this region is the Columbia River plume. Suspended sediment appears as elevated pigment concentrations in the CZCS images and will bias the relationships sought here. Fiedler and Laurs (1990) show that the plume is readily evident in CZCS and AVHRR imagery, most often within $50 \mathrm{~km}$ of the shore but sometimes extending over $100 \mathrm{~km}$ offshore, with a meridional orientation that is modulated seasonally by alongshore wind stress and a summer cross-shelf orientation modulated by offshore Ekman 
Table 1

Spearman rank-order correlation coefficients between wind forcing anomalies of alongshore wind stress (tau) and wind mixing $\left(U^{* 3}\right)$ and eight cross-shelf phytoplankton pigment anomaly metrics over five years $(1979-83)^{*}$

\begin{tabular}{|c|c|c|c|c|c|c|c|c|c|c|}
\hline & & Lag & EOFM1 & EOFM2 & D1.0 & D1.5 & D2.0 & D3.0 & Tot50 km & Tot $100 \mathrm{~km}$ \\
\hline & & 0 & -0.17 & & & & & & & \\
\hline & Tau & 1 & & -0.17 & & & & -0.16 & & \\
\hline \multirow[t]{6}{*}{ Region 1} & & 2 & & & & & & & & \\
\hline & & 0 & & 0.17 & 0.16 & 0.22 & 0.17 & 0.16 & & 0.15 \\
\hline & $U^{* 3}$ & 1 & & 0.16 & & & 0.17 & 0.20 & 0.16 & 0.17 \\
\hline & & 2 & 0.16 & & & & & & & \\
\hline & & 0 & -0.21 & -0.20 & -0.16 & -0.23 & -0.23 & -0.19 & -0.18 & -0.22 \\
\hline & Tau & 1 & -0.31 & -0.35 & -0.26 & -0.33 & -0.34 & -0.41 & -0.35 & -0.39 \\
\hline \multirow[t]{5}{*}{ Region 2} & & 2 & -0.31 & -0.29 & -0.25 & -0.28 & -0.28 & -0.31 & -0.29 & -0.31 \\
\hline & & 0 & & 0.20 & 0.19 & 0.23 & 0.21 & 0.18 & & 0.18 \\
\hline & $U^{* 3}$ & 1 & 0.22 & 0.30 & 0.26 & 0.36 & 0.38 & 0.34 & 0.28 & 0.32 \\
\hline & & $\begin{array}{l}2 \\
0\end{array}$ & 0.35 & 0.33 & 0.28 & 0.37 & 0.39 & 0.37 & 0.34 & 0.37 \\
\hline & Tau & 1 & & -0.19 & -0.2 & -0.27 & -0.22 & -0.20 & & \\
\hline \multirow[t]{6}{*}{ Region 3} & & 2 & & -0.28 & -0.33 & -0.27 & -0.29 & & & -0.19 \\
\hline & & 0 & & & & & 0.15 & & & \\
\hline & $U^{* 3}$ & 1 & & 0.20 & 0.23 & 0.27 & 0.24 & 0.25 & & 0.16 \\
\hline & & 2 & & 0.25 & 0.31 & 0.31 & 0.26 & 0.17 & & 0.19 \\
\hline & & 0 & & -0.2 & -0.17 & -0.16 & -0.17 & -0.19 & & \\
\hline & Tau & 1 & & -0.24 & -0.18 & -0.17 & -0.22 & -0.22 & & -0.17 \\
\hline \multirow[t]{6}{*}{ Region 4} & & 2 & & -0.25 & -0.23 & -0.21 & -0.2 & -0.21 & & -0.17 \\
\hline & & 0 & & & & & & 0.16 & & \\
\hline & $U^{* 3}$ & 1 & & 0.19 & & & 0.18 & 0.19 & & \\
\hline & & 2 & & 0.19 & 0.17 & 0.16 & 0.17 & 0.19 & & \\
\hline & & 0 & & & & & & & & \\
\hline & Tau & 1 & -0.21 & & & & -0.17 & -0.17 & -0.22 & -0.21 \\
\hline \multirow[t]{6}{*}{ Region 5} & & 2 & -0.28 & & & & & -0.19 & -0.27 & -0.25 \\
\hline & & 0 & & & & & & & & \\
\hline & $U^{* 3}$ & 1 & 0.20 & & & & & & 0.19 & 0.18 \\
\hline & & 2 & 0.26 & & & & & 0.19 & 0.25 & 0.22 \\
\hline & & 0 & & & & & & & & \\
\hline & Tau & 1 & & & & & & & & \\
\hline \multirow[t]{4}{*}{ Region 6} & & 2 & 0.16 & -0.19 & 0.20 & & & & & \\
\hline & & 0 & & & & & & & & \\
\hline & $U^{* 3}$ & 1 & & & -0.17 & & & & & \\
\hline & & 2 & -0.21 & 0.26 & -0.27 & -0.19 & & & -0.21 & -0.19 \\
\hline
\end{tabular}

*Correlation values significant at the $90 \%$ level or greater are shown. Italicized values are significant at the $95 \%$ level. See text (Section 3.3) for definitions of lags and cross-shelf pigment metrics.

transport. They show that the strongest plume signature is seen in spring during maximum river discharge and that by the July-September period, pigment concentrations resulting from upwelling mask the plume. The alongshore distance used to define Region 1 is approximately $600 \mathrm{~km}$. While this will reduce the influence of the plume signature on overall averages, cross-shelf pigment patterns, especially in the region nearest shore, are a result of both plume sediment and phytoplankton pigment. 
Among the six study regions, the number of significant correlations is greatest in the Cape Blanco to Cape Mendocino region (Region 2) where virtually all metrics of pigment distribution are correlated with both alongshore wind stress and wind mixing. Correlation coefficients for Region 2 were the highest observed in the study. Strongest correlations between pigment and alongshore wind stress are present at a lag of 1 ten-day period, while strongest correlations between pigment and wind mixing are at a lag of 2 ten-day periods. Both Northern California and Central California also exhibit relatively large numbers of significant linkages between wind forcing and pigment pattern. Unlike Region 2, however, neither the first EOF mode nor the total pigment within $50 \mathrm{~km}$, both measures of pigment variability very nearshore, was correlated with local wind forcing. Off Northern California, significant correlations exist only at lags of 1 and 2 periods with only the distance offshore of the $2.0 \mathrm{mg} \mathrm{m}^{-3}$ isoline correlated to wind at 0 lag. Correlations between pigment and alongshore wind stress are very similar to those between pigment and wind mixing. This changes off Central California (Region 4), however, where correlations remain between cross-shelf pigment and alongshore wind stress, but are weaker, and with fewer pigment metrics for wind mixing. In the two southern-most regions, fewer pigment metrics are correlated to wind forcing than at higher latitudes. These are the only two study regions for which the entire seasonal cycle was used in the correlation calculations and it is possible that inclusion of the winter period of weaker winds reduced evidence of coupling. Off Northern Baja, significant correlations are restricted to lags larger than 0 and are strongest at 2 lag periods. The pigment metrics which do have significant correlations indicate that only concentrations closest to shore (first EOF Mode, higher pigment concentrations, etc.) are related to wind forcing. Southern Baja is the only region in which there are instances of correlations which do not follow the simple model of increased wind mixing or equatorward wind stress leading to increased cross-shelf phytoplankton pigment concentrations.

The large-scale correlation trends described above are consistent with those calculated by Strub et al. (1990), who show that most of the non-seasonal pigment variability is present in patterns north of Point Conception, and that within $100 \mathrm{~km}$ of shore, the significant correlations which account for most of the pigment variance are $U^{* 3}$ and alongshore wind stress. Abbott and Barksdale (1991) show a strong seasonality in the length of high pigment concentration filaments extending offshore from northern and central California, with a minimum in mid-July-August. They show that this is related to a seasonal decrease in wind stress curl. Although our methodology averages over mesoscale filaments, it is likely that seasonal trends in overall filament length such as those described by Abbott and Barksdale contribute to the large-scale cross-shelf means shown to be correlated to wind here.

The extent to which anomalous pigment patterns during the $1983 \mathrm{El}$ Nino affect correlations between wind and pigment over the study period was tested by recalculating the cross-correlations without data from 1983. Table 2 presents these results for the four-year time series (1979-82) in the same format as Table 1. These data show that the overall number and location/metric of crosscorrelation remain similar. Actual correlation values, however, in the regions from Cape Blanco to Point Conception (Regions 2-4), increase substantially indicating a tighter coupling between wind forcing and cross-shelf pigment structure during non-El Nino years. This is consistent with the contention that anomalous patterns during El Nino years are more strongly a result of hydrographic changes within the water column than a direct response to anomalous local winds. Values in Regions 1, 5 and 6 indicate a varying response. In the Pacific Northwest, where pigment 
Table 2

Spearman rank-order correlation coefficients between wind forcing anomalies and eight cross-shelf phytoplankton pigment anomaly metrics over the four-year non-El Nino period 1979-82*

\begin{tabular}{|c|c|c|c|c|c|c|c|c|c|c|}
\hline & & Lag & EOFM1 & EOFM2 & D1.0 & D1.5 & $\mathrm{D} 2.0$ & D3.0 & Tot50 km & Tot $100 \mathrm{~km}$ \\
\hline & & 0 & -0.19 & & & & & -0.19 & -0.18 & -0.18 \\
\hline & Tau & 1 & & & & & & & & \\
\hline \multirow[t]{6}{*}{ Region 1} & & 2 & & & & & & & & \\
\hline & & 0 & & & & 0.20 & 0.19 & & & \\
\hline & $U^{* 3}$ & 1 & & 0.18 & & 0.21 & 0.20 & 0.18 & & \\
\hline & & 2 & 0.18 & & & & & & & \\
\hline & & 0 & -0.26 & -0.23 & -0.18 & -0.26 & -0.28 & -0.25 & -0.24 & -0.27 \\
\hline & Tau & 1 & -0.35 & -0.41 & -0.31 & -0.43 & -0.43 & -0.51 & -0.45 & -0.48 \\
\hline \multirow[t]{6}{*}{ Region 2} & & 2 & -0.34 & -0.39 & -0.34 & -0.32 & -0.32 & -0.35 & -0.34 & -0.39 \\
\hline & & 0 & & 0.29 & 0.32 & 0.31 & 0.29 & 0.24 & 0.23 & 0.29 \\
\hline & $U^{* 3}$ & 1 & 0.27 & 0.43 & 0.45 & 0.49 & 0.48 & 0.43 & 0.37 & 0.44 \\
\hline & & 2 & 0.39 & 0.44 & 0.37 & 0.43 & 0.48 & 0.46 & 0.43 & 0.48 \\
\hline & & 0 & & & & & -0.22 & & & \\
\hline & Tau & 1 & & -0.27 & -0.25 & -0.37 & -0.30 & -0.26 & & \\
\hline \multirow[t]{6}{*}{ Region 3} & & 2 & & -0.38 & -0.43 & -0.34 & -0.35 & -0.24 & & -0.25 \\
\hline & & 0 & & 0.20 & 0.17 & 0.20 & 0.22 & & & \\
\hline & $U^{* 3}$ & 1 & & 0.34 & 0.38 & 0.40 & 0.36 & 0.33 & & 0.24 \\
\hline & & 2 & & 0.36 & 0.42 & 0.40 & 0.33 & 0.27 & & 0.27 \\
\hline & & 0 & & -0.30 & -0.25 & -0.22 & -0.24 & -0.24 & & -0.23 \\
\hline & Tau & 1 & & -0.33 & -0.25 & -0.22 & -0.29 & -0.31 & -0.17 & -0.27 \\
\hline \multirow[t]{6}{*}{ Region 4} & & 2 & & -0.35 & -0.32 & -0.30 & -0.25 & -0.25 & & -0.24 \\
\hline & & 0 & & 0.33 & 0.29 & 0.23 & 0.24 & 0.25 & & 0.24 \\
\hline & $U^{* 3}$ & 1 & & 0.36 & 0.30 & 0.24 & 0.29 & 0.32 & 0.18 & 0.28 \\
\hline & & 2 & & 0.35 & 0.33 & 0.30 & 0.26 & 0.28 & 0.21 & 0.27 \\
\hline & & 0 & & & & & & & & \\
\hline & Tau & 1 & -0.22 & & & & -0.21 & -0.20 & -0.23 & -0.22 \\
\hline \multirow[t]{6}{*}{ Region 5} & & 2 & -0.21 & & & & & & -0.21 & -0.19 \\
\hline & & 0 & & & & & & & & \\
\hline & $U^{* 3}$ & 1 & 0.22 & & & & 0.22 & 0.21 & 0.23 & 0.22 \\
\hline & & 2 & 0.22 & & & & & & 0.22 & 0.20 \\
\hline & & 0 & -0.22 & & & -0.20 & -0.23 & & -0.22 & -0.23 \\
\hline & Tau & 1 & & & & & & & & \\
\hline \multirow[t]{4}{*}{ Region 6} & & 2 & & -0.18 & 0.22 & & & & & \\
\hline & & 0 & 0.19 & & & 0.20 & 0.21 & & 0.21 & 0.21 \\
\hline & $U^{* 3}$ & 1 & & & & & & & & \\
\hline & & 2 & & 0.18 & -0.21 & & & & & \\
\hline
\end{tabular}

*Correlation values significant at the $90 \%$ level or greater are shown. Italicized values are significant at the $95 \%$ level. See text (Section 3.3) for definitions of lags and cross-shelf pigment metrics.

anomalies in 1983 were not strong (Fig. 2), correlations between cross-shelf pigment metrics and wind mixing are fewer, indicating that 1983 data actually contribute to the correlations. Off Northern Baja (Region 5), correlations were similar with or without data from 1983. Off Southern Baja (Region 6), however, removal of the El Nino period results in significant correlations between pigment metrics and wind forcing at zero lag. 


\subsection{SeaWiFS chlorophyll patterns}

NASA's SeaWiFS mission began making global measurements of ocean chlorophyll concentrations in September 1997 and cross-shelf patterns extracted from these data can be compared to those from the CZCS mission. The two data sets measure different bio-optical signals (total pigment versus chlorophyll). Ongoing improvements in both chlorophyll retrievals and atmospheric correction of the SeaWiFS data make the data set examined here preliminary. These factors, however, do not preclude making comparisons of general patterns over the large time and space scales examined here. The time series of cross-shelf chlorophyll profiles over the six study regions from the first 19 months of SeaWiFS data, extracted in a similar manner to the CZCS data, are shown in Fig. 6. Cross-shelf spatial resolution is again $4 \mathrm{~km}$ but temporal resolution is now 8 days. The beginning of the SeaWiFS data coincides with the strong 1997-98 El Nino and we expect that chlorophyll patterns, at least over the first half of the time series, are strongly modulated by anomalous hydrographic conditions. In the four northern study regions, maximum cross-shelf extension of the highest chlorophyll concentrations $\left(1.0-2.0 \mathrm{mg} \mathrm{m}^{-3}\right)$ occurs in the summer of 1998, considerably later in the season (September in the Pacific Northwest and July elsewhere) than was evident in the CZCS data. In general, the early summer upwelling period (April-June), which in many years of the CZCS data exhibited the seasonal maximum in crossshelf pigment concentrations, is not evident in the 1998 SeaWiFS data. Off Baja, the elevated offshore concentrations pointed out by Kahru and Mitchell (2000) in winter of 1997-98 during the height of El Nino conditions are evident. A summer (May-June) maximum in cross-shelf extension is evident in both regions in 1998, generally similar in timing to that in the CZCS data (1979-83). The sharp decrease in concentrations by early July 1998 is very similar to the July decrease evident in 1983. The overall maximum for concentrations greater than $1.0 \mathrm{mg} \mathrm{m}^{-3}$, however, actually occurs at the very end of the time series, in March 1999. Contrasting the two fall (October-December) periods available in the SeaWiFS data, it is evident in the three regions representing the coast from Cape Blanco to Point Conception that elevated concentrations extend further offshore in 1998, when El Nino anomalies have subsided, than in 1997. This is especially true of offshore patterns $\left(0.5 \mathrm{mg} \mathrm{m}^{-3}\right)$ but only weakly so of higher concentrations nearshore $\left(>1.0 \mathrm{mg} \mathrm{m}^{-3}\right)$. These cross-shelf differences are consistent with the relative strength of the two EOF patterns in the El Nino of 1983 shown in Fig. 4. These fall differences are not present off Baja where both years appear substantially similar. Differences were actually reversed in the Pacific Northwest region. Here, maximum differences are evident nearshore in the highest concentrations $\left(>1.5 \mathrm{mg}^{-3}\right)$ and offshore concentrations are similar in the two years. A similar contrast of the two winter periods available (January-March) shows only weak differences between 1998 and 1999 north of Cape Blanco. Relatively strong differences are present south of this. From Cape Blanco to Point Conception, these differences are a larger cross-shelf extension of offshore lower concentrations (the $0.5 \mathrm{mg} \mathrm{m}^{-3}$ isoline) in 1999 and higher concentrations within $40 \mathrm{~km}$ of shore in the El Nino year, perhaps due to higher suspended sediment concentrations from the significantly increased runnoff and/or resuspension from strong storm activity. At both Baja study regions, in contrast to patterns off California, differences between the two winters are less evident offshore in the $0.5 \mathrm{mg} \mathrm{m}^{-3}$ isoline, but reversed and consistent with expected El Nino patterns nearshore (within $100 \mathrm{~km}$ ). Here, concentrations and their offshore extension in the El Nino year are less than those in 1999. It appears that the seasonal offshore expansion of 


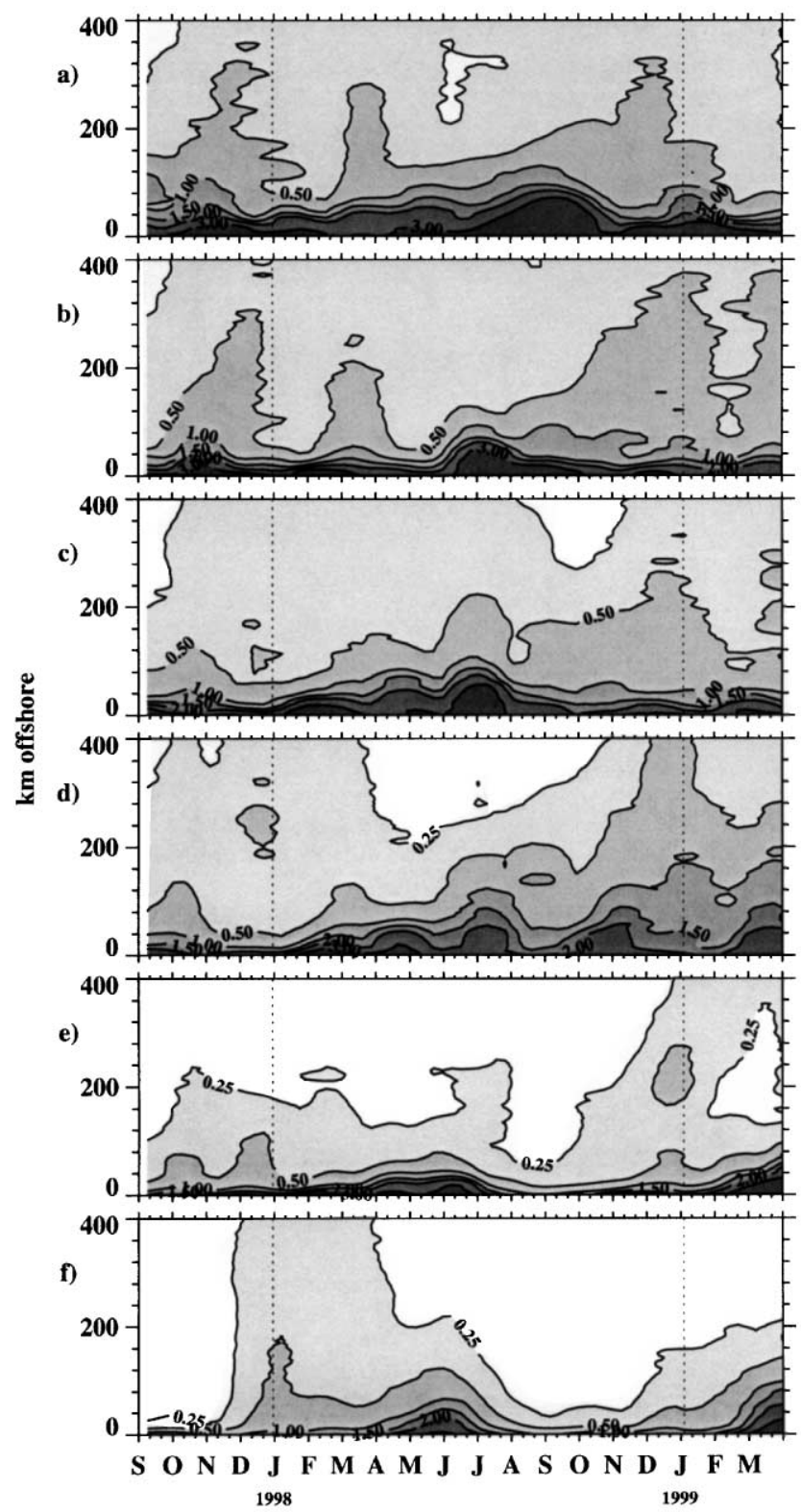

Fig. 6. SeaWiFS chlorophyll concentrations $\left(\mathrm{mg} \mathrm{m}^{-3}\right)$ for the period September 1997-March 1999, contoured as a function of cross-shelf distance and time for Region 1, the Pacific Northwest, Region 2, Cape Blanco to Cape Mendocino, Region 3, Northern California, Region 4, Central California, Region 5, Northern Baja and Region 6, Southern Baja. The temporal resolution of the time series is 8 days and cross-shelf spatial resolution is $4 \mathrm{~km}$. The dashed vertical line delimits the 12 month 1998 annual cycle.

concentrations $>1.0 \mathrm{mg} \mathrm{m}^{-3}$ begins approximately 1.5 months earlier in 1999 (early February) than it did in 1998 (mid-March). This February increase is earlier than that of any year sampled by the CZCS. 


\section{Summary}

Five years of CZCS data characterize the latitudinal, seasonal and interannual variability of the cross-shelf phytoplankton pigment structure in the California Current for the period 1979-83. Meridional and temporal averaging provides a large-scale picture of the width of the region of elevated biological activity. Such patterns provide a previously unquantified background structure against which other measures of biological activity and physical forcing on seasonal and interannual scales can be compared in the California Current.

In each region, concentrations greater than $2.0 \mathrm{mg} \mathrm{m}^{-3}$ are restricted to within $100 \mathrm{~km}$ or less of the coast in early spring (March) and then expand offshore in late spring and summer (May-June) up to $200 \mathrm{~km}$ off California but less off Baja and the Pacific Northwest, coincident with the seasonal maximum in upwelling-favorable wind stress off northern California. A second offshore expansion, usually with lower concentrations $\left(1.0 \mathrm{mg} \mathrm{m}^{-3}\right)$ in late summer (September) is evident in most years. In late summer-fall (September-October) pigment patterns collapse back towards the coast. This seasonal cycle is weakest off Northern Baja. Such patterns document the largescale position of the main frontal region separating offshore more oligotrophic conditions from the more eutrophic eastern boundary current conditions. In addition, previously published data suggest that this boundary provides a biological surrogate for the mean cross-shelf position of the main equatorward current jet of the California Current system in each region.

Interannual variability is primarily a result of differences in the timing and strength of the seasonal offshore maxima between years. The most consistent interannual signal over the latitudinal range of the study is strong negative anomalies in 1983 associated with the El Nino of that year, consistent with patterns previously published. In this year, elevated coastal concentrations $\left(>2.0 \mathrm{mg} \mathrm{m}^{-3}\right)$ never extend as far offshore during the upwelling season and more oligotrophic concentrations $\left(<0.25 \mathrm{mg} \mathrm{m}^{-3}\right)$ intrude closer to the coast for a more extensive portion of the year than in other years. Results suggest that on the scales analyzed here, these El Nino anomalies in cross-shelf distribution did not extend north of Cape Blanco, although interpretation of pigment patterns in this region is complicated by sediment concentrations in the Columbia River plume. Off Northern Baja, reduced cross-shelf distributions in 1983 are similar to those of 1981. EOF decompositions show that the maximum El Nino signal is in a region centered approximately $75 \mathrm{~km}$ offshore and not in the region immediately adjacent to the coast.

Cross-correlations quantify the linkage between cross-shelf pigment distribution and wind forcing parameterized as alongshore wind stress and wind mixing $\left(U^{* 3}\right)$. Strongest correlations are present when pigment patterns lag wind forcing by 1 and 2 ten-day periods. The strongest correlations, as well as the largest number of cross-shelf pigment metrics with significant correlations, are present in the region between Cape Blanco and Cape Mendocino. Correlations are weakest in the Pacific Northwest and generally absent with alongshore wind stress in this region. Two other general patterns which are evident in the correlations are: (1) similar linkages between pigment patterns and both alongshore wind stress and $U^{* 3}$ off Northern California but stronger linkages between alongshore wind stress and cross-shelf pigment than with $U^{* 3}$ off Central California and (2) wind forcing-pigment correlations off Northern Baja are evident only in those metrics of pigment indicative of very nearshore pigment variability.

Lastly, preliminary views of cross-shelf chlorophyll patterns provided by the first 19 months of SeaWiFS data (September 1997-March 1999) suggest that spring-early summer maxima evident 
in CZCS data are not present during the El Nino conditions of early 1998 and that summer maxima are delayed until late in the upwelling season. In the Pacific Northwest, unlike 1983, strong differences are evident between cross-shelf patterns in late 1997 and those of late 1998. Off California, offshore concentrations are higher after El Nino conditions subside towards the end of 1998, but nearshore concentrations are higher during the El Nino, likely due to turbidity. Off Baja, the 1998 summer cross-shelf maximum is similar in timing to that in the CZCS data, but ends abruptly in early July, similar to patterns in 1983. Spring increases in 1999 occur earlier in the season than those of 1998 and earlier than were ever observed in CZCS data.

\section{Acknowledgements}

We thank two anonymous reviewers for helpful comments and Ryan Weatherbee for processing the SeaWiFS data and assistance with the graphics. We gratefully acknowledge support from NASA grants NAG5-6558 and NAG5-6604 and from NSF grants OCE-9711919 and OCE-0000899. This is Contribution Number 169 of the US GLOBEC program, jointly funded by the National Science Foundation and the National Ocean and Atmospheric Administration.

\section{References}

Abbott, M.R., Barksdale, B., 1991. Phytoplankton pigment patterns and wind forcing off central California. Journal of Geophysical Research 96, 14,649-14,667.

Abbott, M.R., Letelier, R.M., 1998. Decorrelation scales of chlorophyll as observed from bio-optical drifters in the California Current. Deep-Sea Research 45, 1639-1667.

Abbott, M.R., Zion, P.M., 1985. Satellite observations of phytoplankton variability during an upwelling event. Continental Shelf Research 4, 661-680.

Abbott, M.R., Zion, P.M., 1987. Spatial and temporal variability of phytoplankton pigment off northern California during Coastal Ocean Dynamics Experiment 1. Journal of Geophysical Research 92, 1745-1756.

Bakun, A., Nelson, C.S., 1991. The seasonal cycle of wind stress curl in subtropical eastern boundary current regions. Journal of Physical Oceanography 21, 1815-1834.

Brink, K.H., Cowles, T.J., 1991. The coastal transition zone program. Journal of Geophysical Research 96, $14,637-14,647$.

Campbell, J.W., Blaisdell, J.M., Darzi, M., 1995. Level-3 SeaWiFS Data Products: Spatial and Temporal Binning Algorithms. NASA Technical Memorandum 104566, Vol. 32.

Chavez, F.P., 1995. A comparison and ship and satellite chlorophyll from California and Peru. Journal of Geophysical Research 100, 24,855-24,863.

Denman, K.L., Abbott, M.R., 1988. Time evolution of surface chlorophyll patterns from cross-spectrum analysis of satellite color images. Journal of Geophysical Research 93, 6789-6798.

Evans, R.H., Gordon, H.R., 1994. Coastal zone color scanner system calibration: a retrospective examination. Journal of Geophysical Research 99, 7293-7307.

Fiedler, P.C., 1984. Satellite observations of the 1982-1983 El Nino along the U.S. Pacific coast. Science 224, 1251-1254.

Fiedler, P.C., Laurs, R.M., 1990. Variability of the Columbia River plume observed in visible and infrared satellite imagery. International Journal of Remote Sensing 11, 999-1010. 
Gordon, H.R., Brown, J.W., Evans, R.H., 1988. Exact Rayleigh scattering calculations for use with the Nimbus-7 coastal zone color scanner. Applied Optics 27, 862-871.

Hickey, B.M., 1998. Coastal oceanography of western North America from the tip of Baja California to Vancouver Island. In: Robinson, A.R., Brink, K.H. (Eds.), The Sea, Vol. 10, Part B. Wiley, New York.

Hill, A.E., Hickey, B.M., Shillington, F.A., Strub, P.T., Brink, K.H., Barton, E.D., Thomas, A.C., 1998. Eastern ocean boundaries. In: Robinson, A.R., Brink, K.H. (Eds.), The Sea, Vol. 10, Part B. Wiley, New York.

Huyer, A.E., Smith, R.L., 1985. The signature of El Nino off Oregon, 1982-1983. Journal of Geophysical Research 90, $7133-7142$.

Huyer, A.E., Sobey, E.J., Smith, R.L., 1979. The spring transition in currents over the Oregon continental shelf. Journal of Geophysical Research 84, 6995-7011.

Kahru, M., Mitchell, B.G., 2000. Influence of the 1997-98 El Nino on the surface chlorophyll in the California Current. Geophysical Research Letters 27, 2937-2940.

Kelly, K.A., 1985. The influence of winds and topography on the sea surface temperature patterns over the northern California slope. Journal of Geophysical Research 91, 7680-7690.

Landry, M.R., Postel, J.R., Peterson, W.K., Newman, J., 1989. Broad-scale distribution patterns of hydrographic variables on the Washington Oregon shelf. In: Landry, M.R., Hickey, B.M. (Eds.), Coastal Oceanography of Washington and Oregon. Elsevier, Amsterdam (Chapter 1).

Lynn, R.J., Schwing, F.B., Hayward, T.L., 1995. The effect of the 1991-93 ENSO on the California Current System. California cooperative Oceanic Fisheries Investigation Reports 36, 19-39.

Lynn, R.J., Simpson, J.J., 1987. The California Current System: the seasonal variability of its physical characteristics. Journal of Geophysical Research 92, 12,947-12,966.

McClain, C.R., 1993. Review of major CZCS applications: U.S. case studies. In: Barale, V., Schlittenhardt, P.M. (Eds.), Ocean Colour: Theory and Applications in a Decade of CZCS Experience. ECSC EEC EAEC, Brussels and Luxembourg, pp. 167-188.

Michaelsen, J., Zhang, X., Smith, R.C., 1988. Variability of pigment biomass in the California Current System as determined by satellite imagery 2. temporal variability. Journal of Geophysical Research 93, $10,883-10,896$.

Millan, R., Alvarez, S., Trees, C.C., 1996. Relationship between deep chlorophyll maximum and surface chlorophyll in the California Current System. California Cooperative Oceanic Fisheries Investigation Reports 37, 241-250.

Pelaez, J., McGowan, J.A., 1986. Phytoplankton pigment patterns in the California Current as determined by satellite. Limnology and Oceanography 31, 927-950.

Rienecker, M.M., Mooers, C.N.K., 1986. The 1982-83 El Nino signal off northern California. Journal of Geophysical Research 91, 6597-6608.

Simpson, J.J., 1983. Large-scale thermal anomalies in the California Current during the 1982-83 El Nino. Geophysical Research Letters 10, 937-940.

Simpson, J.J., Koblinsky, C.J., Pelaez, J., Haury, L.R., Weisenhahn, D., 1986. Temperature-plant pigment optical relations in a recurrent offshore mesoscel eddy near Point Conception, California. Journal of Geophysical Research 91, 12,919-12,936.

Smith, R.C., Zhang, X., Michaelson, J., 1988. Variability of pigment biomass in the California Current System as determined by satellite imagery. 1: spatial variability. Journal of Geophysical Research 93, 10,863-10,882.

Strub, P.T., James, C., 1988. Atmospheric conditions during the spring and fall transitions in the coastal ocean off western United States. Journal of Geophysical Research 93, 15,561-15,584.

Strub, P.T., James, C., 2000. Altimeter derived variability of surface velocities in the California Current system: 2: seasonal circulation and eddy statistics. Deep Sea Research II 47, 831-870.

Strub, P.T., Allen, J.S., Huyer, A., Smith, R.L., 1987. Large-scale structure of the spring transition in the coastal ocean off western United States. Journal of Geophysical Research 92, 1527-1544.

Strub, P.T., James, C., Thomas, A.C., Abbott, M.R., 1990. Seasonal and nonseasonal variability of satellitederived surface pigment concentration in the California Current. Journal of Geophysical Research 95, $11,501-11,530$.

Strub, P.T., Kosro, P.M., Huyer, A., CTZ Collaborators, 1991. The nature of the cold filaments in the California Current System. Journal of Geophysical Research 96, 14,743-14,768. 
Thomas, A.C., Huang, F., Strub, P.T., James, C., 1994. Comparison of the seasonal and interannual variability of phytoplankton pigment concentrations in the Peru and California Current systems. Journal of Geophysical Research 99, 7355-7370.

Thomas, A.C., Strub, P.T., 1989. Interannual variability in phytoplankton distribution during the spring transition along the west coast of N. America. Journal of Geophysical Research 94, 18,095-18,117.

Thomas, A.C., Strub, P.T., 1990. Seasonal and interannual variability of pigment concentration across a California Current frontal zone. Journal of Geophysical Research 95, 13,023-13,042. 